\title{
Ozone response to emission changes: a modeling study during the MCMA-2006/MILAGRO Campaign
}

\author{
J. Song ${ }^{1,2}$, W. Lei ${ }^{1,2}$, N. Bei ${ }^{1}$, M. Zavala ${ }^{1}$, B. de Foy ${ }^{3}$, R. Volkamer ${ }^{2,4}$, B. Cardenas ${ }^{5}$, J. Zheng ${ }^{6}$, R. Zhang ${ }^{6}$, and \\ L. T. Molina ${ }^{1,2}$ \\ ${ }^{1}$ Molina Center for Energy and the Environment, CA, USA \\ ${ }^{2}$ Department of Earth, Atmospheric and Planetary Sciences, Massachusetts Institute of Technology, MA, USA \\ ${ }^{3}$ Department of Earth and Atmospheric Sciences, Saint Louis University, USA \\ ${ }^{4}$ Department of Chemistry and Biochemistry, University of Colorado at Boulder, CO, USA \\ ${ }^{5}$ National Institute of Ecology (INE), Mexico \\ ${ }^{6}$ Department of Atmospheric Sciences, Texas A\&M University, TX, USA
}

Received: 20 October 2009 - Published in Atmos. Chem. Phys. Discuss.: 3 November 2009

Revised: 26 March 2010 - Accepted: 12 April 2010 - Published: 26 April 2010

\begin{abstract}
The sensitivity of ozone production to precursor emissions was investigated under five different meteorological conditions in the Mexico City Metropolitan Area (MCMA) during the MCMA-2006/MILAGRO field campaign using the gridded photochemical model CAMx driven by observation-nudged WRF meteorology. Precursor emissions were constrained by the comprehensive data from the field campaign and the routine ambient air quality monitoring network. Simulated plume mixing and transport were examined by comparing with measurements from the G-1 aircraft during the campaign. The observed concentrations of ozone precursors and ozone were reasonably well reproduced by the model. The effects of reducing precursor emissions on urban ozone production were performed for three representative emission control scenarios. A 50\% reduction in VOC emissions led to 7 to $22 \mathrm{ppb}$ decrease in daily maximum ozone concentrations, while a $50 \%$ reduction in $\mathrm{NO}_{\mathrm{x}}$ emissions leads to 4 to $21 \mathrm{ppb}$ increase, and $50 \%$ reductions in both $\mathrm{NO}_{\mathrm{x}}$ and VOC emission decrease the daily maximum ozone concentrations up to $10 \mathrm{ppb}$. These results along with a chemical indicator analysis using the chemical production ratios of $\mathrm{H}_{2} \mathrm{O}_{2}$ to $\mathrm{HNO}_{3}$ demonstrate that the MCMA urban core region is VOC-limited for all meteorological episodes, which is consistent with the results from MCMA-2003 field campaign; however the degree of the VOC-sensitivity is higher during MCMA-2006 due to lower VOCs, lower VOC
\end{abstract}

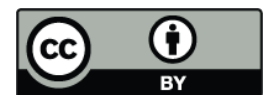

Correspondence to: W. Lei (wflei@mce2.org) reactivity and moderately higher $\mathrm{NO}_{\mathrm{x}}$ emissions. Ozone formation in the surrounding mountain/rural area is mostly $\mathrm{NO}_{\mathrm{x}}$-limited, but can be VOC-limited, and the range of the $\mathrm{NO}_{\mathrm{x}}$-limited or VOC-limited areas depends on meteorology.

\section{Introduction}

The Mexico City Metropolitan Area (MCMA), shown in Fig. 1, is located in the Valley of Mexico. With nearly 20 million inhabitants, Mexico City is North America's most populous city and one of the largest megacities in the world. As a result of rapid increase in population and urbanization, Mexico City suffers from serious air pollution problems (Molina and Molina, 2002, 2004). The urban emissions also significantly influence air quality on the regional scale (MenaCarrasco et al., 2009).

Ozone photochemical production is high in Mexico City due to high emissions of $\mathrm{NO}_{\mathrm{x}}$, VOCs and $\mathrm{CO}$, which provide elevated radical sources, the driving force for urban photochemical activity (Volkamer et al., 2007; Sheehy et al., 2008; Tie et al., 2009). Both measurements and chemical transport model simulations during the MCMA-2003 field measurement campaign (Molina et al., 2007) suggest that $\mathrm{O}_{3}$ production in the source region is VOC limited during the photochemically active periods (Lei et al., 2007) and weakly dependent on meteorological conditions (Lei et al., 2008). Other recent studies (Tie et al., 2007; Torres-Jardon, 2004) also suggest that $\mathrm{O}_{3}$ production in the MCMA is VOClimited, in contrast to results of earlier modeling studies

Published by Copernicus Publications on behalf of the European Geosciences Union. 


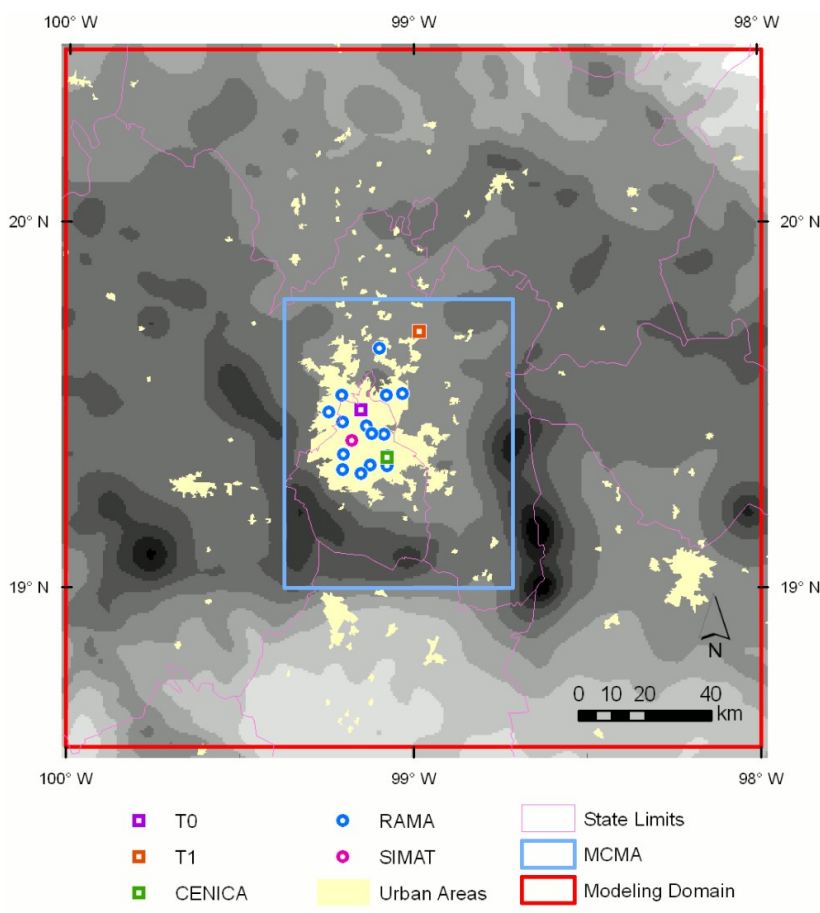

Fig. 1. Air quality modeling domain ( $3 \mathrm{~km}$ by $3 \mathrm{~km}$; the outer red square) with RAMA monitoring sites (blue), CENICA site (green), T0 supersite (purple), and T1 supersite (orange) from the MCMA2006 field campaign. Light blue domain indicates the area covered by 2006 official emission inventory for MCMA, 2006 EI. Light yellow shading denotes urban areas. Topography contour intervals are 400 meter, and the pink contour represents the political state limits.

(West et al., 2004; Sillman and West, 2009). $\mathrm{O}_{3}$ formation is also influenced by the diurnal emission pattern (Ying et al., 2009); for example, changing the diurnal variation of emissions while keeping the total emissions intact has important effects on the $\mathrm{O}_{3}$ concentration.

Analysis of the historical trends of $\mathrm{O}_{3}, \mathrm{CO}$ and $\mathrm{NO}_{\mathrm{x}}$ from the data collected at the air quality monitoring network Red Automática de Monitoreo Atmosférico (RAMA) suggests that ozone formation in Mexico City has moved from less VOC-limited to more VOC-limited regime (Stephens et al., 2008; Zavala et al., 2009a). However, as noted in the study by Lei et al. $(2007,2008)$ and other results from the MCMA2003 field campaign, VOC measurements were limited to a few sites for a relatively short period of time, which may lead to less precise interpretations of the model results.

Another major international field study, MILAGRO (Megacity Initiative: Local and Global Research Observations), was conducted in the MCMA three years later in March 2006 to evaluate the local, regional and global impacts of the Mexico City air pollution plume (Molina et al., 2010). The measurements included a wide range of instruments at ground sites and on aircraft and satellites, which provided unprecedented comprehensive data sets over a wide geographical coverage. MCMA-2006, one of the four MILAGRO components, focused on the emissions within the Mexico City basin and their transport and transformation in the basin using extensive measurements at the T0 supersite, at multiple temporary sites and around the urban area from mobile laboratories.

Urban and regional-scale photochemical models are typically evaluated using ground measurements; simulation using comprehensive suites of aircraft measurements is not as common due to the scarcity of the observed data. The evaluation of 3-D models using aircraft measurements has the potential of providing further insights into model's capabilities for capturing various processes such as chemical transformation, vertical mixing, and transport. In addition, the aircraft data also provide a unique opportunity to evaluate the interaction between emission, meteorology and chemistry near and further from the urban center. During the MILAGRO campaign, a rich array of aircraft measurements of gases and aerosols were obtained and were applied in evaluating model performance and interpreting the $\mathrm{O}_{3}$ formation, evolution and transport in the urban plume from Mexico City (e.g., Tie et al., 2009; Emmons et al., 2010).

Using a 3-D photochemical model, the Comprehensive Air quality Model with extensions version 4.40 (CAMx v4.40), this paper extends the study of Lei et al. $(2007,2008)$ to the MCMA-2006 field campaign. The updated version of CAMx is run over a larger domain and is driven by observationnudged WRF meteorology. The large number of monitoring sites and measurement platforms available during MCMA2006 are used to address two major issues: (1) the evaluation of the model performance on simulating ozone precursors and ozone; and (2) the sensitivity analysis of ozone production to the precursor emissions under different meteorological conditions using the brute-force method, which shows changes in $\mathrm{O}_{3}$ formation between different model runs using different model input (emissions in this study), in conjunction with chemical indicator analysis. These results are compared with the corresponding findings of Lei et al. (2007, 2008) from the MCMA-2003 field campaign. The methodology for this study is described in Sect. 2. Simulated ozone and ozone precursors are evaluated and sensitivity studies are presented and discussed in Sect. 3, followed by comparisons with findings from the previous field campaign.

\section{Methodology}

\subsection{Measurements}

\subsubsection{Ground-based measurements}

The RAMA air quality monitoring network in the MCMA collected surface criteria pollutant concentrations and meteorological parameters at hourly intervals (http://www.sma. df.gob.mx/simat/). A total of 15 monitoring stations, 3 
Table 1. VOC measurements during the MILAGRO campaign that were used in this study.

\begin{tabular}{|c|c|c|c|}
\hline Site/Platform & Analytical method & VOCs used in the analysis & Institution \\
\hline CENICA & GC-FID & ethane, propane, acetylene, toluene, benzene, and xylene & INE, MX \\
\hline \multirow[t]{2}{*}{ SIMAT } & $\begin{array}{l}\text { EC-FOS } \\
\text { GC and GC/MS }\end{array}$ & $\begin{array}{l}\text { Propene-equivalent olefins } \\
\text { ethane, ethene, propane, acetylene, toluene, benzene, xylene, } \\
\text { i-butene, 1-pentene, 1,3-butadiene, t-2-butene, c-2-butene, t- } \\
\text { 2-pentene, and c-2-pentene }\end{array}$ & $\begin{array}{l}\text { WSU } \\
\text { UC Irvine }\end{array}$ \\
\hline & PTRMS & acetaldehyde, toluene, and benzene & Texas A\&M U. \\
\hline \multirow[t]{2}{*}{ T0 } & DOAS & $\begin{array}{l}\text { benzene, toluene, o-xylene, m-xylene, p-xylene, phenol, } \\
\text { cresol, formaldehyde, and benzaldehyde }\end{array}$ & MIT/ Univ. Heidelberg \\
\hline & QC-TILDAS and PTRMS & formaldehyde, acetaldehyde, ethene, toluene, and benzene & ARI \\
\hline G-1 aircraft & GC/PTRMS & $\begin{array}{l}\text { ethene, ethane, propane, benzene, toluene, xylenes, trimethyl- } \\
\text { benzene; } \mathrm{CO} \text { and } \mathrm{O}_{3} \text { (non-VOCs) }\end{array}$ & BNL/PNNL \\
\hline
\end{tabular}

monitoring stations from each city sector (NE, NW, SE, SW, and $\mathrm{CT}$ ), were selected based on the location representativeness and data availability of $\mathrm{CO}, \mathrm{NO}_{\mathrm{x}}$, and $\mathrm{O}_{3}$ during the campaign period. Measurements of $\mathrm{NO}_{\mathrm{x}}$ from RAMA using the chemiluminescence technique more accurately represent gaseous $\mathrm{NO}_{\mathrm{y}}$ (West et al., 2004).

In this study, volatile organic compounds (VOCs) data reported during the MILAGRO Campaign were used to evaluate the VOC emissions in the MCMA, particularly in the urban area. VOCs were measured at T0, T1, SIMAT and CENICA. Figure 1 shows the location of these sites. At T0, the urban supersite located just north of downtown Mexico City, aldehydes and aromatics were measured with Proton Transfer Reaction Mass Spectrometry (PTR-MS) (Zhao and Zhang, 2004; Fortner et al., 2009), formaldehyde and aromatics were measured with long-path Differential Optical Absorption Spectroscopy (DOAS); another set of formaldehyde and ethene were acquired by quantum cascade tunable infrared laser differential absorption spectrometry (QCTILDAS) (Nelson et al., 2004) onboard the Aerodyne mobile lab while parked at $\mathrm{T} 0$; and canister samples of ethene, alkanes, and aromatics were analyzed by Gas Chromatography (GC) and GC/MS. At the CENICA site, located in an urban commercial/residential area with fewer industries than $\mathrm{T} 0$, alkanes and aromatics from canisters were speciated by GC analysis using Flame Ionization Detection (GC-FID). At the SIMAT site $\left(19^{\circ} 24^{\prime} \mathrm{N}, 99^{\circ} 10^{\prime} \mathrm{W}\right)$, close to the center of the city, VOC concentrations and fluxes were measured using eddy covariance (EC) techniques coupled with Fast Olefin Sensor (FOS) (Velasco et al., 2009). Measurements at the T1 site (de Gouw et al., 2009) located in the northeast urban outskirt and other sites outside the MCMA were not included as they are downwind sites, containing less information about urban emissions. Table 1 lists the VOCs used in this study with their corresponding measurement techniques and operation institutions during the MCMA-2006 field campaign. A detailed summary of the ground-based and aircraft measurements of VOCs can be found in Apel et al. (2010).

\subsubsection{G-1 aircraft measurements}

During MILAGRO-2006 several aircraft were deployed in and around the MCMA to collect chemical and meteorological data, including the G-1 operated by DOE (ftp://ftp.asd. bnl.gov/pub/ASP\%20Field\%20Programs/2006MAXMex/) and the C-130 operated by NCAR (http://mirage-mex.acd. ucar.edu/Measurements/C130/index.shtml). In this study only measurements from G-1 were included, since the flights covered a smaller spatial and temporal domain, which is the scope of this study. There were 15 G-1 flights measuring chemical species over the MCMA, especially above T0 and T1 supersites. Details on the G-1 aircraft flights over Mexico City during MILAGRO are provided in Kleinman et al. (2008) and Nunnermacker et al. (2008). Data used in this study are 10 -second average values for $\mathrm{CO}$ and $\mathrm{O}_{3}$ on 7 March, and $\mathrm{CO}, \mathrm{O}_{3}$ and speciated VOCs on 27 March. $\mathrm{CO}$ and $\mathrm{O}_{3}$ were measured using VUV fluorescence analyzer and UV absorption detector, respectively (Springston et al., 2005). Canister samples of ethene, alkanes and aromatics were collected every 1-2 $\mathrm{min}$, and analyzed by GC. Ten-second averaged aromatics were also measured with PTR-MS.

\subsection{Model description}

Concentrations of air pollutants were simulated using CAMx v4.40 (Environ, 2006) with the SAPRC99 chemical mechanism (Carter, 2000). CAMx simulates emission, advection, dispersion, chemical transformation and physical removal of air pollutants on an Eulerian 3-dimensional grid. The 6 modeling episodes selected for this study are described in Sect. 2.3 along with their meteorological classification. A gridded urban scale domain centering in Mexico City with 
the resolution of $3 \mathrm{~km}, 70 \times 70$ grid cells was used in this study (labeled as "modeling domain" in Fig. 1) with 16 vertical layers extending from the surface to about $7 \mathrm{~km}$ a.g.l.

Meteorological data inputs, including wind, temperature, height/pressure, water vapor, vertical diffusivity, and clouds/precipitation, were derived from the Advanced Research WRF (ARW) model (WRF v2.2.1; Skamarock et al., 2005). The model simulations adopted three one-way nested grids with horizontal resolutions of 36,12 , and $3 \mathrm{~km}$ and 35 sigma levels in the vertical direction. The grid cells used for the three domains were $145 \times 95,259 \times 160$, and $193 \times 193$, respectively. The WRF model was initialized at 00:00 UTC every day and integrated for $36 \mathrm{~h}$. The physical parameterization schemes included the modified Kain-Fritsch cumulus scheme (KF-Eta; Kain and Fritsch, 1993), the WRF Single Moment (WSM) three-class microphysics (Hong et al., 2004), and the Yonsei State University (YSU) boundary layer scheme (Noh et al., 2003). National Centers for Environmental Prediction (NCEP) global final (FNL) analysis were used to create initial and boundary conditions. To improve the accuracy of the simulated fields, "observationnudging"-based continuous four-dimensional data assimilation (FDDA) scheme (WRF-FDDA; Liu et al., 2005) was employed in the domain with a horizontal resolution of $3 \mathrm{~km}$. Multi-level upper-air observations were assimilated, including radar wind profilers, tethered balloon measurements, controlled meteorological balloon observations, aircraft observations, additional soundings inside the Mexico city basin operated during the MILAGRO campaign, and routine soundings observations. The vertical diffusion coefficients $\left(\mathrm{k}_{v}\right)$ were reconstructed from the state variables of the WRF-FDDA output using the CMAQ scheme (Byun, 1999). According to de Foy et al. (2008), the CMAQ scheme overestimates the $k_{v}$ values. These were therefore reduced to 30$40 \%$ as was done for the MCMA-2003 campaign (see Lei et al., 2008). This $\mathrm{k}_{v}$ scaling has little influence on chemical concentrations at nighttime and early morning (because of the patch treatment for the minimum $k_{v}$ values in the near surface layer), but it affects the day time concentrations (as much as $15 \%$ for surface $\mathrm{CO}$ ) when there is active turbulent mixing.

Anthropogenic emissions used in the model were constructed from the official emission inventory (EI) for the year 2006 for the MCMA (http://www.sma.df.gob.mx/simat/ programas_ambientales/anexo). The annual emissions in the MCMA from different sources (mobile, area, and point source) were temporally resolved, chemically speciated, and then spatially resolved into grid cells with a resolution of $2.25 \mathrm{~km}$. In areas outside the MCMA, official emissions data from point sources were available, but area and mobile emissions were not available. To account for these emissions, anthropogenic emissions outside the MCMA from the area and mobile sources were estimated based on the population distribution as follows:
$E_{i, j}=r_{i} \times \frac{E_{j, \mathrm{MCMA}}}{P_{\mathrm{MCMA}}} \times \mathrm{SF}$

where $r_{i}$ is population density in the grid cell obtained from a high resolution population density map in the year of $2005, E_{j, \mathrm{MCMA}}$ and $P_{\mathrm{MCMA}}$ are the total anthropogenic emissions of pollutant $\mathrm{j}$ and the population in the MCMA, respectively. SF are the population-based scaling factors that account for differences in emission intensities with respect to the MCMA, ranging linearly from 0.1 to 0.3 for $r<200$ heads $/ \mathrm{km}^{2}$ (mainly rural areas) and $r<15000$ heads $/ \mathrm{km}^{2}$ (mainly urban areas with much higher production activities).

Lei et al. $(2007,2008)$ suggested that the overall VOC emissions in the official MCMA EI were underestimated by $40 \%$ with variations among VOC species. Based on the ground measurements made at CENICA site and at T0, adjustments were made to the emissions of lumped VOCs species (see Sect. 3.1 below). When the measurements were unavailable, adjustment factors from the MCMA-2003 study were used.

Biogenic emissions were estimated using the MEGAN v2.04 model (Model of Emissions of Gases and Aerosols from Nature) developed by Guenther et al. (2006, 2007). MEGAN uses land cover data with a high resolution (less than $1 \mathrm{~km}$ ), emission factors specific to the interested region, and time- and location-specific meteorological data. MEGAN estimates biogenic emissions as follows:

$F=\mathrm{EF} \cdot \gamma_{\mathrm{LAI}} \cdot \gamma_{P} \cdot \gamma_{T} \cdot \gamma_{\mathrm{AGE}}$

where $F$ is the emission flux $\left(\mu \mathrm{g} \mathrm{m}^{-2} \mathrm{hr}^{-1}\right)$, EF is the emission factor at standard condition of $303 \mathrm{~K}\left(\mu \mathrm{g} \mathrm{m}^{-2} \mathrm{hr}^{-1}\right)$, $\gamma_{\mathrm{LAI}}, \gamma_{P}, \gamma_{T}$, and $\gamma_{\mathrm{AGE}}$ are dimensionless scalars that describe the response of emission to diurnal variation in leaf area index (LAI), photosynthetic photon flux density (PPFD), ambient temperature, and leaf age, respectively. The emissions estimated from MEGAN on the spatial resolution of $1 \mathrm{~km}$ were then lumped into the SAPRC99 species groups.

The chemical and boundary conditions were the same as those used in the MCMA-2003 studies (Lei et al., 2007), which were constructed based on measurements, except they were downscaled by about $10 \%$ considering a larger model domain used in this study.

\subsection{Meteorological episodes}

$\mathrm{O}_{3}$ production under different meteorological conditions was examined. During MCMA-2003, three meteorological episode types were identified (de Foy et al., 2005). $\mathrm{O}_{3}$-South days had a convergence zone in the south of the city that moved northwards into the early evening, causing high ozone peaks in the south of the city. $\mathrm{O}_{3}$-North days had stronger westerly winds aloft causing a convergence zone oriented north-south through the city with pollutant exhaust to the north and high ozone peaks in the north. Cold Surge days 
had strong cold and wet winds from the north flushing the basin to the south, bringing rain and cloudiness with them.

During MILAGRO, six meteorological episode types were identified: the three episode types classified during MCMA$2003\left(\mathrm{O}_{3}\right.$-South, $\mathrm{O}_{3}$-North and Cold Surge $)$ applicable to MILAGRO, and extra three $\left(\mathrm{O}_{3}-\mathrm{SV}, \mathrm{O}_{3}-\mathrm{CnvS}\right.$ and $\mathrm{O}_{3}-\mathrm{CnvN}$, see below) to account for meteorological conditions at the beginning and at the end of the campaign (de Foy et al., 2008). The first part of the campaign had dry northwesterly winds aloft with strong southward transport at the surface and no convergence zones in the basin. These "South-Venting" days had clean air and rapid flushing of the urban plume to the south. The second part of the campaign was characterized by afternoon rains. These were classified into two subtypes depending on the location of the maximum amount of rainfall: convection-South and Convection-North. Convection takes place when there are weak westerly winds aloft combined with humid conditions in the basin. Surface convergence in the afternoon leads to convection and rainfall in the basin with the location to the north or south dependent on the balance of the winds from the plateau to the north and from the gap in the southeast. Cluster analysis of radiosonde profiles and surface wind measurements showed that conditions during MILAGRO were climatologically representative of the warm dry season, suggesting that an analysis of $\mathrm{O}_{3}$ production during the different episodes of MILAGRO would be representative of general conditions in the basin for this season (de Foy et al., 2008).

To minimize the influence from the transition of different meteorological conditions on the selected episode, each episode was selected when at least 3 consecutive days had similar meteorological condition: 1-7 March 2006 as $\mathrm{O}_{3}$-South Venting $\left(\mathrm{O}_{3}\right.$-SV), 9-11 March 2006 as $\mathrm{O}_{3}$ North $\left(\mathrm{O}_{3}-\mathrm{N} 1\right)$, 15-17 March 2006 as $\mathrm{O}_{3}$-South $\left(\mathrm{O}_{3}-\mathrm{S}\right)$, 18 20 March 2006 as $\mathrm{O}_{3}$-North $\left(\mathrm{O}_{3}\right.$-N2), 24-26 March 2006 as $\mathrm{O}_{3}$-Convection South $\left(\mathrm{O}_{3}-\mathrm{CnvS}\right)$, and 27-30 March 2006 as $\mathrm{O}_{3}$-Convection North $\left(\mathrm{O}_{3}-\mathrm{CnvN}\right) . \mathrm{O}_{3}-\mathrm{N} 1$ was a period with flow towards the north and included one of the highest ozone days (11 March), and the $\mathrm{O}_{3}-\mathrm{N} 2$ was a holiday period.

Mexico City was in the Central Standard Time zone at the time of the campaign (CST=UTC -6 ); all results in this paper will be reported in local time (LT=CST).

\section{Results and discussions}

Simulations of 1-h averaged ozone precursors and ozone concentrations using CAMx v4.40 were compared to measurements made during different meteorological episodes. A day prior to each modeled episode was used for model "spinup" to reduce the effects of chemical initial conditions, hence results of these days are not included.
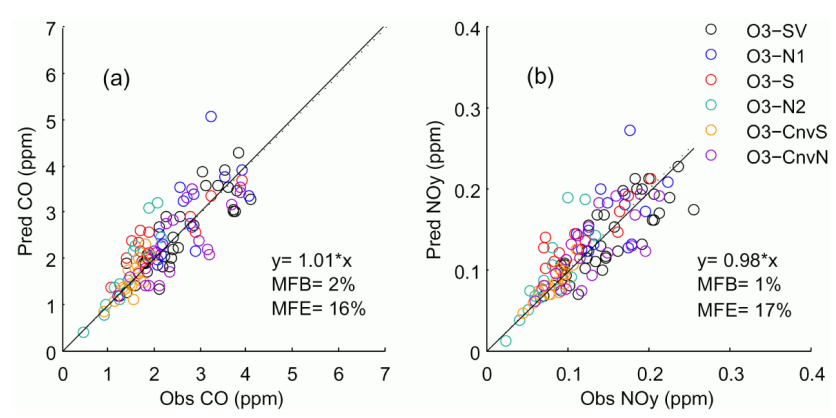

Fig. 2. Scatter plot of simulated and observed concentrations of (a) $\mathrm{CO}$ and (b) $\mathrm{NO}_{\mathrm{y}}$ averaged over 15 RAMA monitoring sites during all episodes. Scatter plots only show datasets during 07:0011:00 LT for $\mathrm{CO}$ and $\mathrm{NO}_{\mathrm{y}}$. Performance statistics are also shown. The dashed lines indicate a perfect positive correlation, and each color indicates a different meteorological episode.

\subsection{Adjustment of emission inventory}

For ozone precursors and ozone, simulations with the official emission inventory were compared with the measurements taken from 15 RAMA monitoring stations, the CENICA site and the T0 supersite. Figure 2 shows that peak $\mathrm{CO}$ and $\mathrm{NO}_{\mathrm{y}}$ concentrations were well simulated, with no mean fractional bias and low fractional errors (see definitions below), suggesting that no adjustments to the emission inventory were necessary for these species. Analysis of speciated VOC concentrations suggested that emissions of most alkanes were underestimated by factors of $2-3$ in mass except $>\mathrm{C} 4$ alkanes (ALK4, ALK5 in the SAPRC99 speciation with OH rate constant $\left(\mathrm{k}_{\mathrm{OH}}\right)$ of $5-10 \times 10^{3}$ and $>1.0 \times 10^{3} \mathrm{ppm}^{-1} \mathrm{~min}^{-1}$, respectively, mainly pentanes or higher alkanes). The number of >C4 alkanes measured during MCMA-2006 campaign was not adequate for lumping, which did not allow us to perform measurement-model comparisons; the adjustment factors obtained during the MCMA-2003 study, 1.4 and 0.6 for ALK4 and ALK5 respectively, were instead used (Lei et al., 2007, 2008). The downscaling of ALK5 emissions may be due also to their low concentrations and the incomplete detection of these species by the GC-FID measurement. Nevertheless the uncertainty in ALK5 emissions is not expected to substantially influence the $\mathrm{O}_{3}$ chemistry due to their low concentrations and low VOC reactivity (Velasco et al., 2007). Ethylene (ETHE) emissions were underestimated by $40 \%$ while emissions of other olefins were overestimated by up to $50 \%$. The emissions of aromatics were overestimated by a factor of 2 . It should be noted that the measurements of a limited number of aromatic species during the campaign were extrapolated to include more species such that the observation-model comparisons of lumped aromatics can be made (ARO1 are aromatics with $\mathrm{k}_{\mathrm{OH}}<2 \times 10^{4} \mathrm{ppm}^{-1} \mathrm{~min}^{-1}$, consisting primarily of toluene, benzene and other monoalky benzenes, and $\mathrm{ARO} 2$ are aromatics with $\mathrm{k}_{\mathrm{OH}}>2 \times 10^{4} \mathrm{ppm}^{-1} \mathrm{~min}^{-1}$, mainly xylenes and 

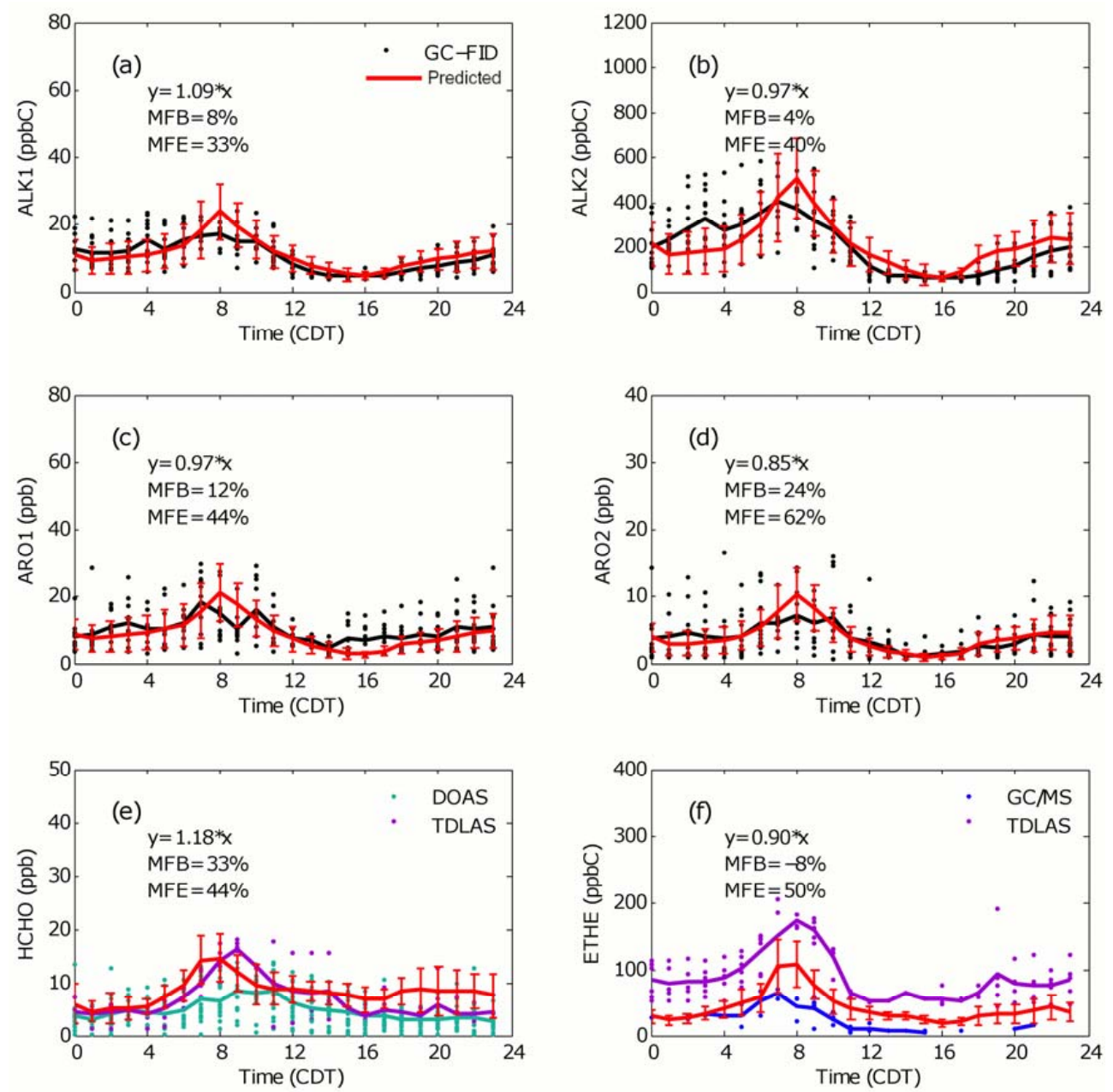

Fig. 3. Comparisons of simulated and observed VOC concentrations after the emissions were adjusted. (a) ALK1, (b) ALK2, (c) ARO1, (d) ARO2 at CENICA, and (e) HCHO, (f) ETHE at T0. Measurements within 5 and 95 percentiles are included. Each colored dot indicates individual VOC measurement, and the solid line with corresponding color indicates the average of those measurements. Different color indicates different measurement techniques: GC-FID data in black, DOAS data in light green, QC-TILDAS data in purple, GC and GC/MS data in blue. Hourly averaged simulated VOC concentrations with \pm 1 standard deviation (averaged over the time concurrent to the VOC observations at CENICA and T0 in March 2006) are shown in red. Also shown are the agreement statistics ( $y=\operatorname{simulations,} x=\mathrm{observations})$ during 6-11 a.m.

polyalkyl benezens). The extrapolation was derived from the MCMA-2003 canister data and DOAS measurements (Velasco et al., 2007; Volkamer et al., 2005; Lei et al., 2007). Also, emissions of aldehydes were underestimated by factors of 3-4.5. Figure 3 compares VOC concentrations simulated using emissions adjusted for the above underestimates/overestimates with the observed values at CENICA and T0. The statistical metrics shown in the figure, mean fractional bias (MFB) and mean fractional error (MFE), are defined as follows:
Mean fractional bias (MFB)

$=\frac{1}{N} \sum_{1}^{N}\left(\frac{\text { pred }- \text { obs }}{(\text { pred }+ \text { obs }) / 2}\right) \times 100 \%$

Mean fractional error (MFE)

$=\frac{1}{N} \sum_{1}^{N}\left(\frac{\mid \text { pred }- \text { obs } \mid}{(\text { pred }+ \text { obs }) / 2}\right) \times 100 \%$

where $N$ is the number of observations. In contrast with mean normalized bias (MNB) and mean normalized gross error (MNGE) statistical metrics, MFB and MFE do not put 
great emphasis on performance when observations are low (Boylan and Russell, 2006).

After the emissions were adjusted, the agreement between simulated and observed VOCs was within \pm 1 standard deviation. It should be noted that some VOCs, for example $\mathrm{HCHO}$ and ETHE, measured concurrently and independently by different groups at the same site showed large variations (Fig. 3e and f). The difference can be partially explained by the different temporal coverage of the different measurements and the spatial inhomogeneity. ARI mobile lab, where the QC-TILDAS measurement was taken, was stationed at T0 on the ground $\sim 50 \mathrm{~m}$ away from the T0 building whereas other ground measurements were sampled at the rooftop of a building a few tens of meters a.g.l. This inhomogeneity can cause the measurement difference of the primary species $\mathrm{C}_{2} \mathrm{H}_{4}$ shown in Fig. 3f. The moderate difference in HCHO shown in Fig. 3e is likely due to the fact that DOAS is a longpath measurement stationed at the building rooftop. Mean values of the measurements for these two lumped species by different groups were used for the emission adjustments of these species in our modeling. The post-adjusted ARO2 emissions seem to be still underestimated by $15 \%$.

The measurement data at SIMAT were not included during the emission adjustment process (they were not available when we completed the model runs), instead they were used to verify the adjustment. Figure 4 shows the comparison of the simulated propene-equivalent olefin concentrations in compound with the FOS measurements. The propene equivalence here refers to the sensitivity response of the FOS instrument to olefin species with respect to propene (Velasco et al., 2009), which is different from the OH-reactivity based definition introduced by Chameides et al. (1992). The simulated effective OLE concentrations were calculated from different SAPRC99 OLE model species (ETHE, OLE1, OLE2 and ISOP) weighted by their FOS response factors and their contributions to the standard VOC mixture used in the SAPRC99 mechanism (Lei et al., 2009; Velasco et al., 2009). The good agreement justifies the adjustment of olefin emissions.

A summary of total weekday emissions by source category in MCMA from 2006 official emission inventory and the adjusted emissions are listed in Table 2. Overall, the VOC emissions from the official emission inventory were adjusted by $18-23 \%$ with the variability depending on the day-to-day variation in biogenic emissions. These variations are even more significant on the domain-wide emissions, leading to larger variations in overall total VOC emissions. The total VOC adjustment in the MCMA is smaller than the value used by Lei et al. $(2007,2008)$ (1.26 vs. 1.65), probably due to the VOC emissions changes over the years in both the emission inventories and in actual emissions. Zavala et al. (2009b) find that the mobile emission factors of a few VOC species (mainly aldehydes and aromatics) are reduced between 2003 and 2006 in the MCMA (by about 20\%). Although the measured VOC species are only a small portion of the total VOCs, and the reported quantity is the emission fac-

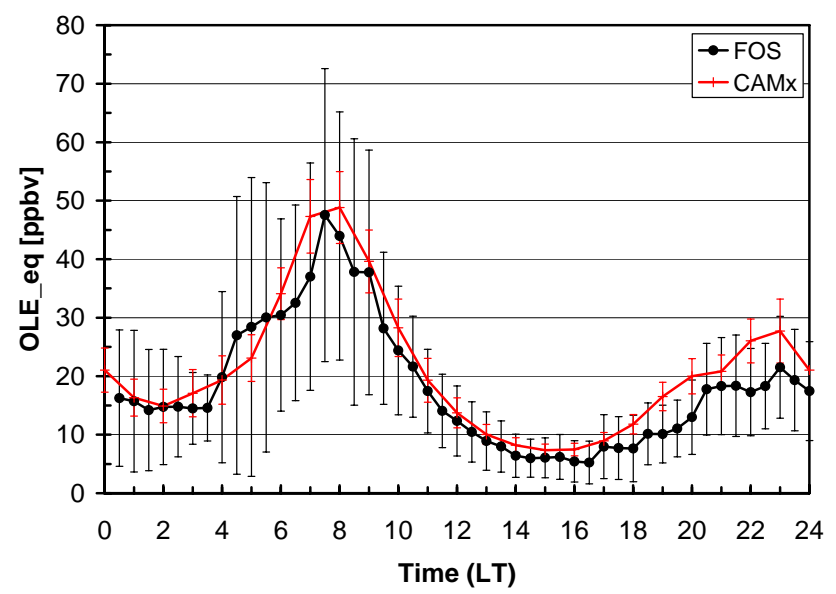

Fig. 4. Comparison of simulated (in red) and measured (in black) average diurnal variations of propene-equivalent olefin concentrations in compound at SIMAT. Error bars represent \pm 1 standard deviations, indicating the inter-diurnal variability. Data were averaged over 10-28 March 2006.

tor, it may be a strong indication of the emissions reduction of VOCs in 2006 compared to 2003 . It should be noted that there are no sufficient VOC measurements available to reach a quantitative conclusion about the VOC emission changes between 2003 and 2006. The size of the VOC measurement dataset for evaluation and the variability in measurements may also contribute to the difference.

The adjusted emissions (base case) of $\mathrm{CO}, \mathrm{NO}_{\mathrm{x}}$ and VOCs in the MCMA-2006 are 1990, 195 and 700-743 ktons/yr, respectively. Compared to those of MCMA-2003, which are 1938, 183 and $900 \mathrm{ktons} / \mathrm{yr}$ (Lei et al., 2007, 2008), the $\mathrm{NO}_{\mathrm{x}}$ emissions increased slightly (6\%), but the VOCs emissions decreased by about $20 \%$, leading to changes in the $\mathrm{NO}_{\mathrm{x}} / \mathrm{VOC}$ ratio from 4.9 in 2003 to 3.7 (mass -based) in 2006. In particular, the total emissions of highly reactive VOCs (alkenes and aromatics) decrease significantly (16\% and $48 \%$, respectively), resulting in the reduction of VOC reactivity in 2006 compared to 2003. The larger decrease in the aromatics emissions may also reflect the uncertainty of the method used in the evaluation (e.g., the extrapolation) and indicates the needs for further evaluations. These changes in $\mathrm{NO}_{\mathrm{x}}$ and VOCs and lower VOC reactivity in 2006 could affect the characteristics of ozone formation in the MCMA. For example, the lower $\mathrm{VOC} / \mathrm{NO}_{\mathrm{x}}$ ratio and lower VOC reactivity may contribute to the lower radical levels observed during the MCMA-2006 campaign compared to MCMA-2003 (Shirley et al., 2006; Dusanter et al., 2009a, b).

\subsection{Simulation of ozone precursors and ozone concentrations at surface}

Before a model can be applied for $\mathrm{O}_{3}$ sensitivity studies it is essential to demonstrate its capability to accurately simulate 

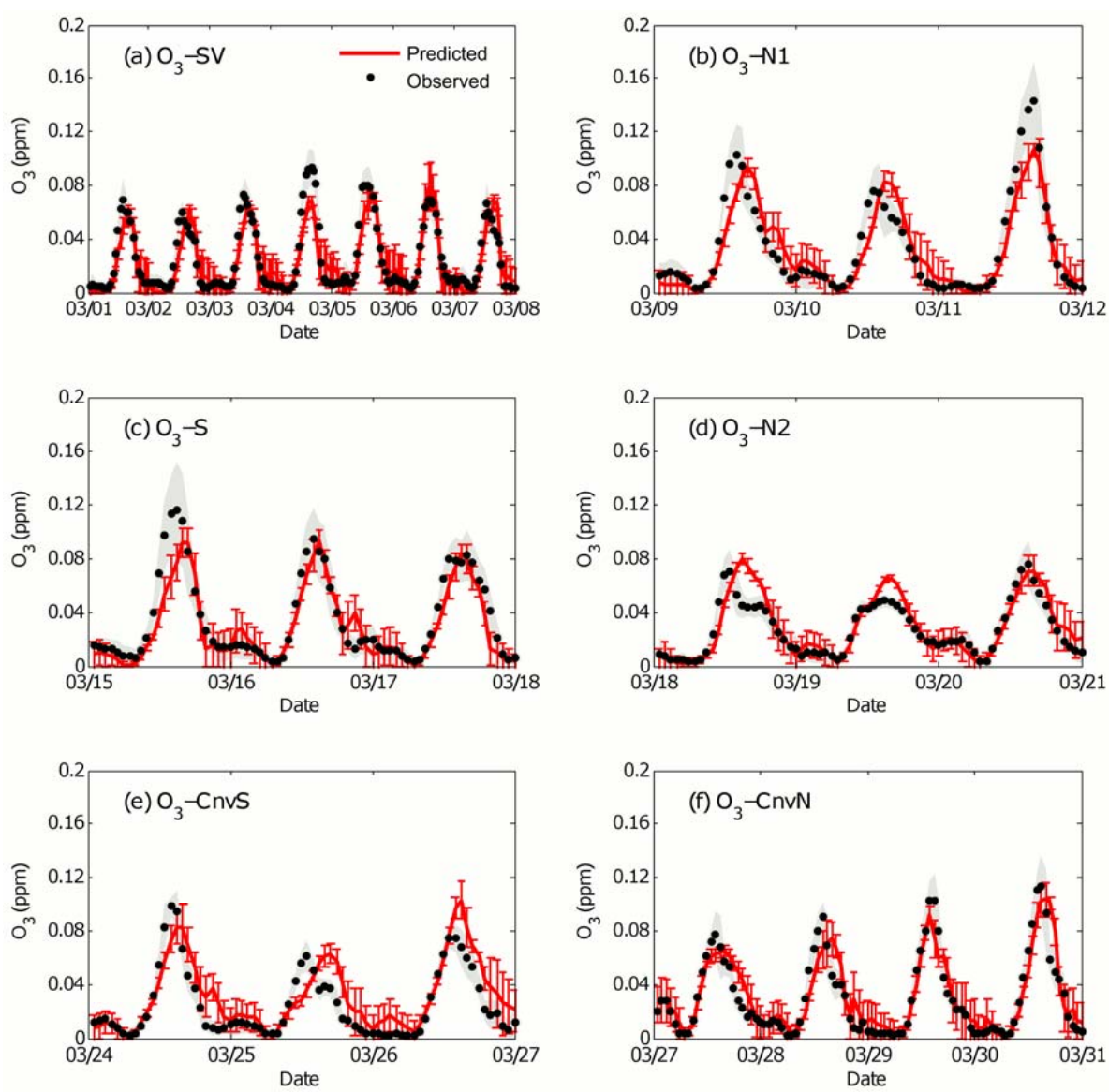

Fig. 5. Comparison of hourly simulated concentrations of $\mathrm{O}_{3}$ with the observations averaged over 15 RAMA monitoring sites during (a) $\mathrm{O}_{3}-\mathrm{SV}$, (b) $\mathrm{O}_{3}-\mathrm{N} 1$, (c) $\mathrm{O}_{3}-\mathrm{S}$, (d) $\mathrm{O}_{3}-\mathrm{N} 2$, (e) $\mathrm{O}_{3}-\mathrm{CnvS}$, and (f) $\mathrm{O}_{3}-\mathrm{CnvN}$ episode. Shaded area and error bars indicate \pm 1 standard deviation of the observation and simulation, respectively.

Table 2. Comparison between total weekday emissions by pollutant type and source category in the MCMA from the 2006 official emission inventory and the adjusted emissions used in this study. Units are in tons day ${ }^{-1}$. Numbers in parenthesis indicate the domain-wide emissions.

\begin{tabular}{llll|lllll}
\hline & \multicolumn{2}{c}{2006 official EI } & \multicolumn{5}{c}{ Adjusted EI } \\
\hline Source & $\mathrm{CO}$ & $\mathrm{NO}_{\mathrm{x}}$ & $\mathrm{VOC}$ & $\mathrm{CO}$ & $\mathrm{NO}_{\mathrm{x}}$ & \multicolumn{3}{c}{ VOCs } \\
\hline & & & & & & Total & OLE & ARO \\
\hline Area & 5460 & 470 & 1160 & 5460 & 470 & 1520 & - & - \\
Point & 20 & 60 & 330 & 20 & 60 & 300 & - & - \\
Biogenic & 0 & 0 & 80 & 10 & 0 & $110-220$ & - & - \\
Total & 5480 & 540 & 1570 & 5490 & 540 & $1920-2040$ & 106 & 198 \\
& & & & $(12040)$ & $(850)$ & $(6440-7280)$ & $126^{\mathrm{a}}$ & $382^{\mathrm{a}}$ \\
\hline
\end{tabular}

a Numbers in adjusted MCMA emissions in 2003.

the observations. We now compare simulations and concentrations of ozone and ozone precursors both at ground level and aloft.

As depicted in Fig. 5, the observed concentrations of ozone were reasonably well reproduced by the model except for a few days, 4, 11, and 25 March 2006 which are all Saturdays. On 4 and 11 March, the spatial distribution of ozone concentrations showed that the location of the plume was accurately simulated, but the simulated magnitude was much lower (figures not shown). This might be because emissions on Saturdays were reduced by $15 \%$ in the simulations. Data analysis suggests that peak concentrations of 


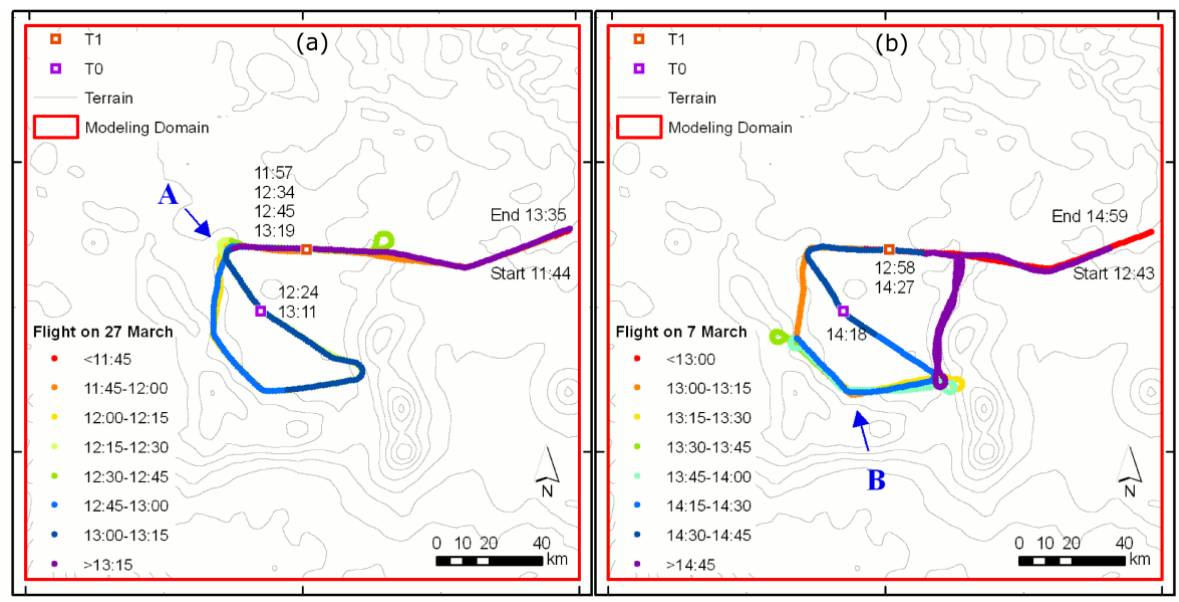

Fig. 6. Flight track of the G-1 aircraft on (a) 27 and (b) 7 March with starting, ending, and sampling time stamps at each supersite from MCMA-2006 field campaign are shown; T0 (purple) and T1 (orange). Rainbow colors correspond to the measurement time. Topography contour intervals are $400 \mathrm{~m}$. Letter A and B denote the location where flights passed multiple times.

primary pollutants may be lower on Saturdays, but the overall emissions may be similar to week days (Stephens et al., 2008; Stremme et al., 2009). On 25 March, the peak hours were not captured by the model, which might be due to the meteorology.

Differences of ozone profiles during different meteorological episodes can be explained by different wind patterns and characteristics of each episode. As strong, dry and clean southerly winds flushed out the basin during South-Venting days, the observed ozone concentrations in the basin during these episodes were lower than those from other episodes (Fig. 5). During $\mathrm{O}_{3}-\mathrm{S}$ and $\mathrm{O}_{3}-\mathrm{N} 1$, on the other hand, pollutants accumulated in the south or north of the city which led to high observed ozone concentrations. Although $\mathrm{O}_{3}-\mathrm{N} 1$ and $\mathrm{O}_{3}-\mathrm{N} 2$ fell into the same meteorological episode category, the daily maximum ozone concentrations averaged over RAMA sites differed by $40 \%$ (107 ppb during $\mathrm{O}_{3}-\mathrm{N} 1$ vs. $64 \mathrm{ppb}$ during $\mathrm{O}_{3}-\mathrm{N} 2$ for episode-averaged peak ozone) mostly due to lower anthropogenic emissions (30-40\% less) during the holiday period and also due to stronger southerly winds during $\mathrm{O}_{3}-\mathrm{N} 2$ that vented the pollutants more efficiently. High $\mathrm{O}_{3}$ concentrations were still observed under the convection conditions $\left(\mathrm{O}_{3}-\mathrm{CnvS}\right.$ and $\left.\mathrm{O}_{3}-\mathrm{CnvN}\right)$ because the convection usually occurred in the late afternoon.

As shown in Fig. 2, simulated morning hours (07:0011:00 LT) concentrations of $\mathrm{CO}$ and $\mathrm{NO}_{\mathrm{y}}$ agreed well with the observations. MFB and MFE during all the episodes were $2 \%$ and $16 \%$ for $\mathrm{CO}$ and were $1 \%$ and $17 \%$ for $\mathrm{NO}_{\mathrm{y}}$. The agreements of ozone for all the episodes were fairly good with MFB and MFE values of $-1 \%$ and $24 \%$, respectively. Excluding weekend values, ozone concentrations showed better agreement with MFB and MFE values of $-2 \%$ and $15 \%$, respectively.

\subsection{Comparisons with G-1 aircraft measurements}

Two of the days when the G-1 aircraft flew over the urban area, 27 and 7 March, were selected as examples to compare the $\mathrm{CO}$ and ozone concentrations aloft. Good agreement between simulated and observed $\mathrm{CO}$ and $\mathrm{O}_{3}$ concentrations at the surface (not shown) were obtained for both days. Figure 6 shows the G-1 flight path on both days with the overpass time at each supersite as well as starting and ending times of each flight. On 27 March, classified as $\mathrm{O}_{3}-\mathrm{CnvN}$, the flight focused more on the northwestern MCMA and T1 supersite and traversed an elevated pollutant plume four times (location "A" in Fig. 6a). Simulated concentrations were interpolated in time and space to the time and location of the data along the flight track. Figure 7 shows the comparisons of $\mathrm{O}_{3}$ and $\mathrm{CO}$. The agreement between the model and the observations on 27 March was remarkably good, especially for $\mathrm{O}_{3}$, indicating the pollution plume was well captured by the model. On 7 March, classified as $\mathrm{O}_{3}-\mathrm{SV}$, the plane flew over southwestern MCMA 5 times (Location "B" in Fig. 6b) and captured the high $\mathrm{CO}$ and $\mathrm{O}_{3}$ concentrations between 13:06 and 14:09LT. The measured plume width was about $15 \mathrm{~km}$, whereas the simulated plume was about $28 \mathrm{~km}$ wide, which resulted in lower and longer-lasting elevated concentrations for both $\mathrm{CO}$ and $\mathrm{O}_{3}$ (Fig. 7b). Although quantitatively speaking the model did not simulate well the magnitude and width of the plume, qualitatively it captured both the location and the peak time. This was representative of other days where the simulated urban plumes were in qualitative agreement with the observations

The aircraft measurements on 27 March also provided speciated VOC data for further model evaluation. Figure 8 shows the comparison of simulated VOCs and observations along with the flight path. Agreement between simulated 

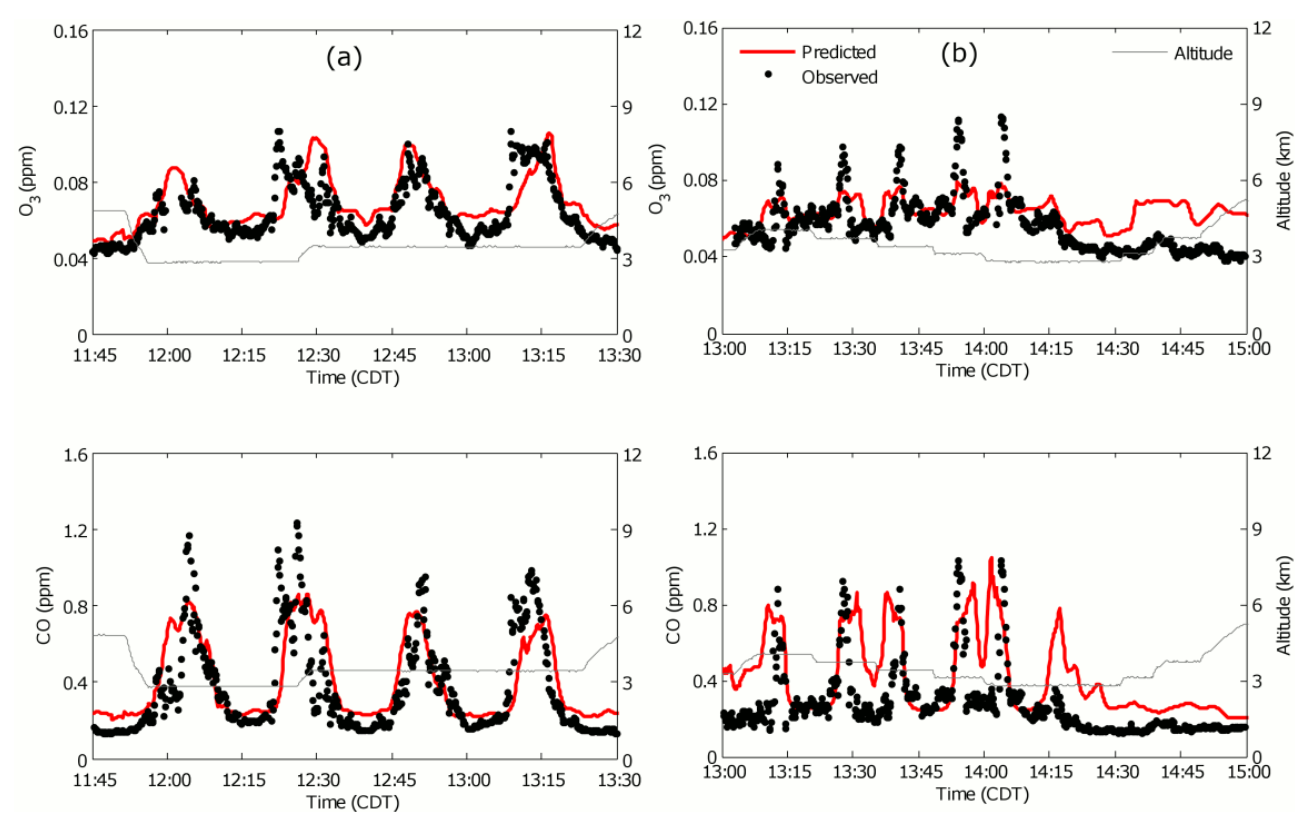

Fig. 7. Time series for ozone and CO along the G-1 flight track on (a) 27 and (b) 7 March. Each measurement was taken at a 10-second interval, and simulations were temporally and spatially interpolated simulations to correspond each measurement. Gray line indicates the G-1 flight altitude.

and observed VOCs was good, especially with ethene and alkanes. On the other hand, peak concentrations of ARO2 were underpredicted, consistent with the underestimation indicated by T0 comparison (Fig. 3d), suggesting that the ARO2 emissions may need to be improved, as pointed out in Sect. 3.1. However, the underestimate of emissions (15\%) is not adequate to explain the significant underprediction of ARO2. This may also imply that the modeled plume is possibly chemically over-active such that most of the highly active ARO2 is chemically lost in lower altitudes (note that the pollution plume is well captured by the model).

In summary the model qualitatively and to some extent quantitatively captured the urban plume; this indicates that the model represents the main features of the transport and mixing processes, as well as the interaction of emission, transport and chemistry. Together with the excellent agreement of the near-surface concentrations, this provides further confidence in the model's ability to simulate ozone concentrations, which provides a viable case from which to proceed with the $\mathrm{O}_{3}$ sensitivity investigation.

\subsection{Characteristics of ozone formation during the MCMA-2006 Field Campaign}

\subsubsection{Ozone formation and its sensitivity to emissions}

Relationships among net photochemical formation rate $\left(\mathrm{P}\left(\mathrm{O}_{\mathrm{x}}\right)\right)$, where $\mathrm{O}_{\mathrm{x}}$ is defined as $\mathrm{O}_{3}+\mathrm{NO}_{2}$, radical primary sources $(Q)$, and $\mathrm{NO}_{\mathrm{x}}$ oxidation rate $\left(\mathrm{P}\left(\mathrm{NO}_{\mathrm{z}}\right)\right)$ help to determine if the $\mathrm{O}_{3}$ formation is in a VOC- or $\mathrm{NO}_{\mathrm{x}}$-limited regime. Analysis limiting the data between 12:00 and 17:00 LT during each episode period within the urban area is presented in Fig. 9. As shown in Fig. 9, $\mathrm{O}_{\mathrm{x}}$ formation is largely determined by the available radical sources (Fig. 9a), and the reaction of radicals with $\mathrm{NO}_{\mathrm{x}}$ is the dominant radical sink regardless of meteorological conditions (Fig. 9b), which implies that the reactions of $\mathrm{OH}$ radicals with VOCs in the urban area are the rate-limiting step for $\mathrm{O}_{3}$ formation (Daum et al., 2000; Kleinman et al., 1997; Kleinman, 2005; Sillman, 1995). The mean $\mathrm{O}_{\mathrm{x}}$ production efficiency, defined as $\mathrm{P}\left(\mathrm{O}_{\mathrm{x}}\right) / \mathrm{P}\left(\mathrm{NO}_{\mathrm{z}}\right)$ in this study and calculated from data pairs in Fig. 9, is 7, which is in excellent agreement with the measurement-based estimates of 7 by Wood et al. (2009) in the urban area during the MCMA-2006 campaign.

The effects of reducing precursor emissions were analyzed for three representative emission control strategies: $50 \%$ reduction in total VOC emissions (50\% VOC), 50\% reduction in total $\mathrm{NO}_{\mathrm{x}}$ emissions $\left(50 \% \mathrm{NO}_{\mathrm{x}}\right)$, and $50 \%$ reduction in both VOC and $\mathrm{NO}_{\mathrm{x}}$ emissions (50\% All). The results are shown in Fig. 10 and Table 3. For the base case, peak ozone concentrations averaged over the 15 RAMA monitoring sites occurred at 13:00-15:00 LT depending on the episode. A 50\% reduction in VOC emissions led to $11.8-$ $30.7 \mathrm{ppb}(16.6-32.8 \%)$ decrease in peak $\mathrm{O}_{3}$ concentrations averaged over the 15 monitoring sites in the MCMA, varying with episodes, while a $50 \%$ reduction in $\mathrm{NO}_{\mathrm{x}}$ emissions led to $6.5-31.8 \mathrm{ppb}(9.2-37.7 \%)$ increase in the peak averages, and $50 \%$ reductions in both $\mathrm{VOC}$ and $\mathrm{NO}_{\mathrm{x}}$ emissions led to $4.9-13.3 \mathrm{ppb}(6.8-14.2 \%)$ decrease in the peak averages. Both the absolute and relative changes are larger 

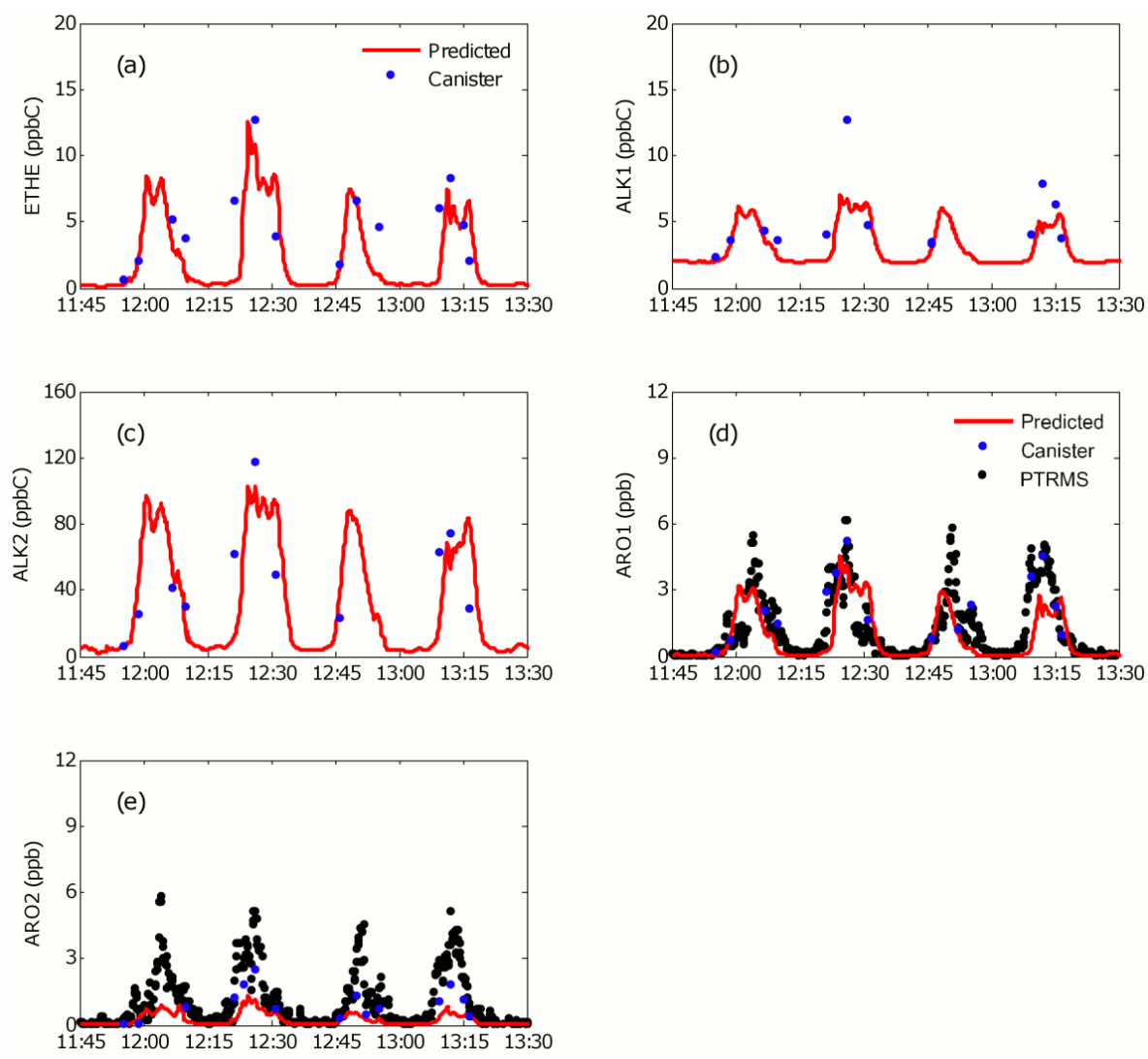

Fig. 8. Time series for VOCs on 27 March are shown. Canister measurements were collected within 1-2 min (blue dots), and real-time VOCs analyzed by PTRMS were taken at 10-s intervals (black dots). Simulations were temporally and spatially interpolated to correspond to each measurement.

Table 3. Percentage changes of episode averaged peak ozone concentrations due to emission reductions under different meteorological conditions.

\begin{tabular}{lcccc}
\hline Episode & ${\text { Base case } \mathrm{O}_{3}(\mathrm{ppb})}^{50 \% \mathrm{VOC}(\%)}$ & $50 \% \mathrm{NO}_{\mathrm{x}}(\%)$ & $50 \% \mathrm{All}(\%)$ \\
\hline $\mathrm{O}_{3}-\mathrm{SV}$ & 66.9 & -24.5 & 36.3 & -8.1 \\
$\mathrm{O}_{3}-\mathrm{N} 1$ & 93.5 & -32.8 & 18.4 & -14.2 \\
$\mathrm{O}_{3}-\mathrm{S}$ & 84.3 & -34.2 & 37.7 & -7.5 \\
$\mathrm{O}_{3}-\mathrm{N} 2$ & 70.9 & -16.6 & 9.2 & -6.9 \\
$\mathrm{O}_{3}-\mathrm{CnvS}$ & 80.4 & -26.9 & 14.7 & -9.3 \\
$\mathrm{O}_{3}-\mathrm{CnvN}$ & 78.0 & -23.7 & 23.6 & -6.8 \\
\hline
\end{tabular}

than obtained during MCMA-2003 (Lei et al., 2007, 2008), mainly due to the changes in estimated VOC emissions. The ozone concentrations from 50\% VOC followed the trend of the base case in the early morning and late afternoon; however, daytime ozone concentrations were significantly lower than those from the base case. Also, peak ozone concentrations from $50 \%$ VOC reduction generally occurred $1-2 \mathrm{~h}$ later than those from the base case. On the other hand, $\mathrm{NO}_{\mathrm{x}}$ reductions produced significant increases in peak ozone throughout the day, and peak ozone concentrations occurred
1-2 $\mathrm{h}$ earlier than those from the base case. Reductions in both $\mathrm{VOC}$ and $\mathrm{NO}_{\mathrm{x}}$ emissions generally followed the trend of the base case during the daytime with changes in episodeaveraged daily maximum 1-h ozone concentrations (4.9 ppb decrease from $\mathrm{O}_{3}-\mathrm{N} 2$ to $13.3 \mathrm{ppb}$ decrease from $\mathrm{O}_{3}-\mathrm{N} 1$ ), but followed the trend of $50 \% \mathrm{NO}_{\mathrm{x}}$ in the early morning and late afternoon. These results indicate that the $\mathrm{O}_{3}$ formation is VOC-sensitive in the MCMA urban area.

During different meteorological episodes, the magnitude of changes, as well as the peak ozone timing was different 

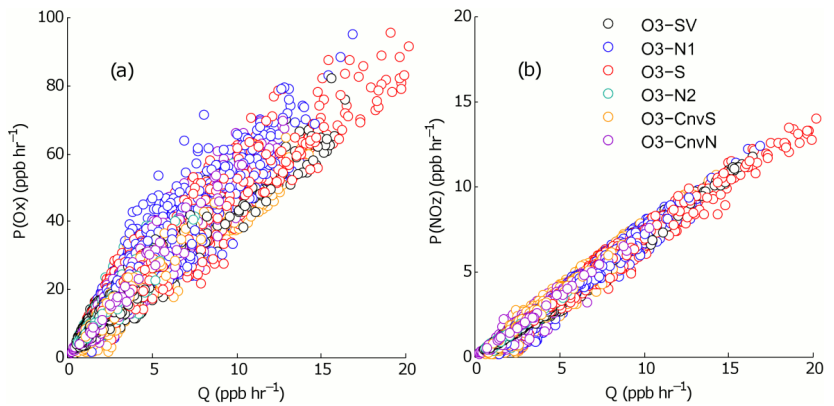

Fig. 9. Indicators examining the VOC- or $\mathrm{NO}_{\mathrm{x}}$-limited conditions for urban area during 12:00-17:00 LT; Relationships between primary radical production rates and (a) $\mathrm{O}_{\mathrm{x}}$ formation rate and (b) $\mathrm{NO}_{\mathrm{X}}$ oxidation rate.

for different emission control scenarios, with the largest changes in the $\mathrm{O}_{3}-\mathrm{S}$ episode and the smallest changes during the convection events. These results suggest that the MCMA urban region is VOC-limited during the ozone peak hours as well as during the morning and late afternoon. Under VOC-limited conditions, ozone formation is limited by the amount of available radicals for $\mathrm{NO} \rightarrow \mathrm{NO}_{2}$ conversion $\left(\mathrm{RO}_{2} / \mathrm{HO}_{2}+\mathrm{NO} \rightarrow \mathrm{RO} / \mathrm{OH}+\mathrm{NO}_{2}\right)$ that eventually leads to $\mathrm{O}_{3}$ production. Meanwhile $\mathrm{NO}_{2}$-radical reactions become the dominant radical chemical sink. These findings are consistent with results from the MCMA-2003 field campaign (Lei et al., 2007, 2008; Volkamer et al., 2007; Sheehy et al., 2008) as well as with MILAGRO measurement-based conclusions (Nunnermacker et al., 2008; Wood et al., 2009; Stephens et al., 2008).

Figure 11 shows the spatial distribution of changes in peak ozone concentrations due to reductions in emissions of VOCs, $\mathrm{NO}_{\mathrm{x}}$, and both during each meteorological episode. Compared to the base case, $50 \%$ reductions in VOC emissions led to domain-wide decrease in ozone concentrations, up to $55.8 \mathrm{ppb}$ with maximum decreases in the high ozone areas (Fig. 11b). This is always the case with few exceptions in polluted urban atmosphere because of high $\mathrm{NO}_{\mathrm{x}}$, limited radicals and the magnitude of VOC emissions reduction. In contrast, 50\% reductions in $\mathrm{NO}_{\mathrm{x}}$ emissions led to either increases or decreases in peak ozone concentrations, depending on the location (Fig. 11c). In the urban area, ozone concentrations increased by up to $56.3 \mathrm{ppb}$ due to the reductions in $\mathrm{NO}_{\mathrm{x}}$ emissions while they decreased in mountain/rural areas. The spatial distributions of changes in ozone concentrations were also sensitive to the direction of the plume, which was highly dependent on the meteorological episode. When both VOC and $\mathrm{NO}_{\mathrm{x}}$ emissions were reduced, ozone concentrations in the urban area either increase or decrease depending on the direction of the plume (Fig. 11d). For example, ozone concentrations at peak hours during $\mathrm{O}_{3}-\mathrm{N} 1$ decreased by up to $26.0 \mathrm{ppb}$ in the urban area when both VOC and $\mathrm{NO}_{\mathrm{x}}$ emissions were reduced; however, the concentration at the same location increased by up to $6.9 \mathrm{ppb}$ during $\mathrm{O}_{3}-\mathrm{CnvS}$. This also suggests that ozone formation in the MCMA urban area is VOC-sensitive.

\subsubsection{Indicator $\left(\mathbf{P}_{\mathrm{H}_{2} \mathrm{O}_{2}} / \mathbf{P}_{\mathrm{HNO}_{3}}\right)$ analysis}

Due to its robust theoretical backgrounds, a strong correlation between its constant ratio and the $\mathrm{P}\left(\mathrm{O}_{\mathrm{x}}\right)$ ridgeline and the least uncertainty, the ratio of the production rates of hydrogen peroxide and nitric acid $\left(\mathrm{P}_{\mathrm{H}_{2} \mathrm{O}_{2}} / \mathrm{P}_{\mathrm{HNO}_{3}}\right)$ has been widely used in chemical indicator analysis to examine the sensitivity of ozone formation (Sillman, 1995; Tonnesen and Dennis, 2000). It has been established in many urban areas in North America that if the $\mathrm{P}_{\mathrm{H}_{2} \mathrm{O}_{2}} / \mathrm{P}_{\mathrm{HNO}_{3}}$ ratio is higher than 0.35 , it is defined as $\mathrm{NO}_{\mathrm{x}}$-limited regime; if the ratio is lower than 0.06, it is defined as VOC-limited regime, and in between it is defined as a transition regime (Tonnesen and Dennis, 2000). Figure 12a depicts the relationships between $\mathrm{P}\left(\mathrm{O}_{\mathrm{x}}\right)$ and $\mathrm{P}_{\mathrm{H}_{2} \mathrm{O}_{2}} / \mathrm{P}_{\mathrm{HNO}_{3}}$ at 12:00-17:00 LT under two different emission reduction scenarios: $50 \%$ VOC and $50 \% \mathrm{NO}_{\mathrm{x}}$. Here we define the transition regime as the situation where the difference in the $\mathrm{O}_{3}$ production rate between the two emission scenarios is less than $5 \%$ relative to the base case. This definition is similar to the one defined by Sillman (1999) in the context of urban $\mathrm{O}_{3}$ chemistry. By this definition, ozone formation in the MCMA is $\mathrm{NO}_{\mathrm{x}}$-limited when the $\mathrm{P}_{\mathrm{H}_{2} \mathrm{O}_{2}} / \mathrm{P}_{\mathrm{HNO}_{3}}$ ratio is higher than 0.24, VOC-limited when the ratio is lower than 0.14 , and transitional when the ratio is between 0.14 and 0.24 , and it varies little with different meteorological conditions. These results are within the criteria that were specified from previous studies (Tonnesen and Dennis, 2000). Note that Fig. 12a encompasses all the episodes including weekends (shown in gray). Most gray data points overlapped with other data points, indicating that the relationship between $\mathrm{P}\left(\mathrm{O}_{\mathrm{x}}\right)$ and $\mathrm{P}_{\mathrm{H}_{2} \mathrm{O}_{2}} / \mathrm{P}_{\mathrm{HNO}_{3}}$ during weekends is similar to the one during weekdays.

The $\mathrm{P}_{\mathrm{H}_{2} \mathrm{O}_{2}} / \mathrm{P}_{\mathrm{HNO}_{3}}$ criteria were applied to examine the spatial distribution of $\mathrm{VOC}$ and $\mathrm{NO}_{\mathrm{x}}$ limitations. Figure $12 \mathrm{~b}$ gives an example of the $\mathrm{P}_{\mathrm{H}_{2} \mathrm{O}_{2}} / \mathrm{P}_{\mathrm{HNO}_{3}}$ spatial variation on 7 and 27 March, two days with a high percentage of VOCand $\mathrm{NO}_{\mathrm{x}}$-limited regime, respectively. As shown in the figure, there is a large variation in the spatial distributions of VOC- or $\mathrm{NO}_{\mathrm{x}}$-limited regime in the afternoon among different meteorological episodes: ozone formation in the high $\mathrm{NO}_{\mathrm{x}}$ emitting urban areas are sensitive to VOC, whereas the ozone formations in the mountains or low $\mathrm{NO}_{\mathrm{x}}$ emitting rural areas are more sensitive to $\mathrm{NO}_{\mathrm{x}}$, i.e., ozone formations in the urban area are VOC-limited regardless of the meteorological episodes; however, in areas outside the city with relatively low- $\mathrm{NO}_{\mathrm{x}}$ emissions it can be either $\mathrm{NO}_{\mathrm{x}}$ - or VOC-limited regime depending on the meteorological episode. In terms of the urban area, controlling VOCs would be a more effective way to reduce ozone concentrations than controlling $\mathrm{NO}_{\mathrm{x}}$; however, it is essential to understand that the sensitivity of VOC- or $\mathrm{NO}_{\mathrm{x}}$-limited regime changes over time and space. 

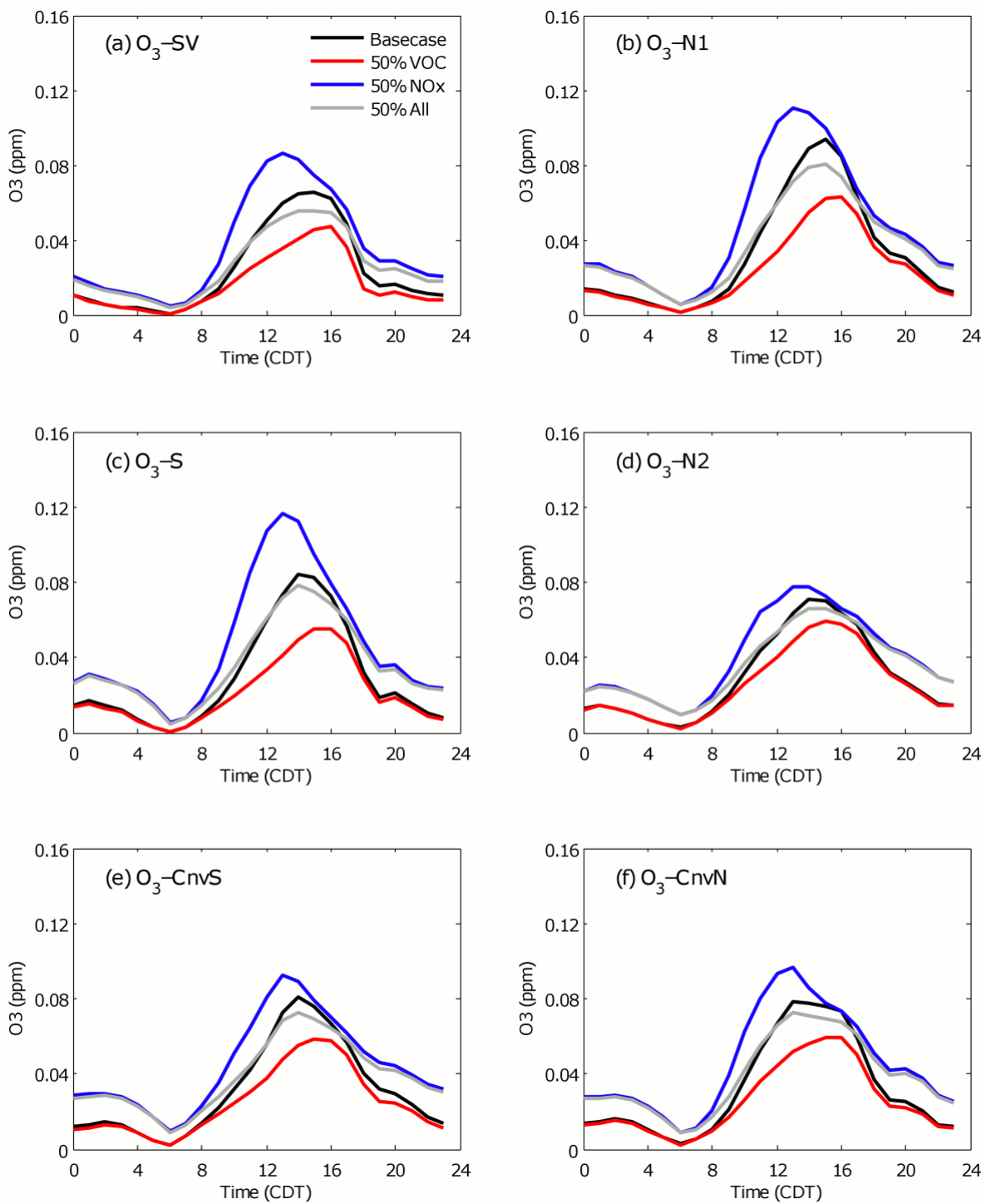

Fig. 10. Time series showing the sensitivity of ozone production to ozone precursors under different meteorological conditions, compared to the base case. Data were averaged over 15 RAMA monitoring stations and over each period. Black line indicates the base case, red indicates the ozone concentrations with $50 \%$ reductions in VOC emissions, blue indicates those with $50 \%$ reductions in $\mathrm{NO}_{\mathrm{x}}$ emissions, and gray indicates those with $50 \%$ reductions in both $\mathrm{VOC}$ and $\mathrm{NO}_{\mathrm{x}}$ emissions.

\subsection{3 $\mathrm{NO}_{\mathrm{x}}-\mathrm{VOC}$ sensitivity vs. chemical aging}

Lei et al. $(2007,2008)$ show that the $\mathrm{O}_{3}$ sensitivity in the MCMA is closely related to chemical aging $\left(\mathrm{NO}_{\mathrm{z}} / \mathrm{NO}_{\mathrm{y}}\right)$ of the urban plume, and point out that as the plume becomes chemically aged, the $\mathrm{O}_{3}$ formation tends to shift from VOClimited to $\mathrm{NO}_{\mathrm{x}}$-limited, but no criteria have been established for the transition. In this study, we attempt to establish the criteria by analyzing the $\mathrm{P}\left(\mathrm{O}_{\mathrm{x}}\right)-\mathrm{NO}_{\mathrm{z}} / \mathrm{NO}_{\mathrm{y}}$ relationship under different emissions, in order to use measurements to assess the $\mathrm{O}_{3}$ formation regime. Although both the $\mathrm{O}_{3}$-chemical aging relationship and the $\mathrm{P}\left(\mathrm{H}_{2} \mathrm{O}_{2}\right) / \mathrm{P}\left(\mathrm{HNO}_{3}\right)$ relation discussed above attempt to use measurements to assess the $\mathrm{O}_{3}$ formation characteristics, they are different in that the former is derived from the radical chemistry and reflects the in situ chemistry while the latter is usually associated with plume dilution and transport and is embedded with the plume history.

Figure 13 illustrates the percentage change in $\mathrm{P}\left(\mathrm{O}_{\mathrm{x}}\right)$ $\left(\triangle \mathrm{P}\left(\mathrm{O}_{\mathrm{x}}\right)\right)$ as a function of base case $\mathrm{NO}_{\mathrm{z}} / \mathrm{NO}_{\mathrm{y}}$ at $12: 00$ 17:00 LT in the MCMA urban region under different meteorological conditions during the MILAGRO campaign when emissions are reduced by $50 \%$. Figure $13 \mathrm{a}-\mathrm{f}$ shows the change on weekdays while Fig. 13g shows the change during weekends. We find that $\Delta \mathrm{P}\left(\mathrm{O}_{\mathrm{x}}\right)$ generally decreases with increasing chemical aging and shifts from positive to negative 


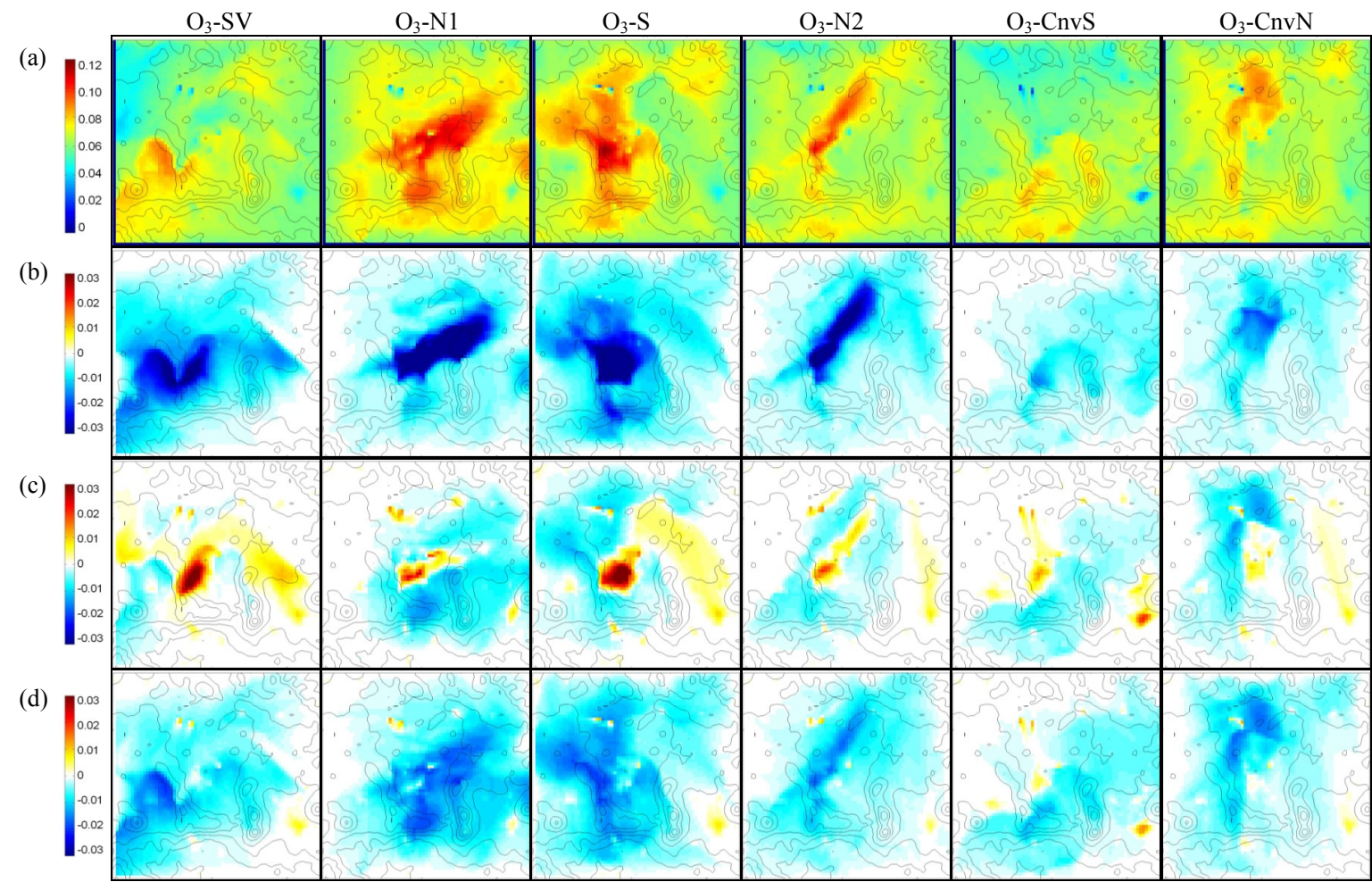

Fig. 11. Spatial distribution of peak ozone changes due to the changes in emissions under different meteorological conditions. (a) Peak ozone concentration in the base case, (b) ozone change with $50 \%$ VOC, (c) ozone change with $50 \% \mathrm{NO}_{\mathrm{x}}$, and (d) ozone change with $50 \%$ VOC and $\mathrm{NO}_{\mathrm{x}}$. Snapshots were taken at peak ozone hours, units are in ppm.

when the $\mathrm{NO}_{\mathrm{x}}$ emissions are reduced by $50 \%, \Delta \mathrm{P}\left(\mathrm{O}_{\mathrm{x}}\right)$ increases gradually with increasing $\mathrm{NO}_{z} / \mathrm{NO}_{\mathrm{y}}$ when the VOC emissions are reduced by $50 \%$, while $\Delta \mathrm{P}\left(\mathrm{O}_{\mathrm{x}}\right)$ remains constant with $\mathrm{NO}_{\mathrm{z}} / \mathrm{NO}_{\mathrm{y}}$ when emissions of both $\mathrm{NO}_{\mathrm{x}}$ and VOCs are reduced by $50 \%$. These characteristics are consistent under different meteorological conditions, and no noticeable differences are found between weekdays and weekends. Furthermore, it can be established that $\mathrm{O}_{3}$ formation is VOC-limited when $\mathrm{NO}_{\mathrm{z}} / \mathrm{NO}_{\mathrm{y}}<0.45$, but is $\mathrm{NO}_{\mathrm{x}}-$ limited when $\mathrm{NO}_{\mathrm{z}} / \mathrm{NO}_{\mathrm{y}}>0.60$, with the latter occurring significantly less frequently. It should be noted that these criteria may change with location and with different base emissions. For example, a Lagrangian-wise analysis by Lei et al. (2008) shows that the urban plume becomes $\mathrm{NO}_{\mathrm{x}}$-limited when $\mathrm{NO}_{\mathrm{z}} / \mathrm{NO}_{\mathrm{y}}>0.8$ after the plume travels outside of the MCMA urban area during the MCMA-2003 campaign.

The $\mathrm{O}_{3}$ sensitivity is discussed above in the context of emissions and chemical aging represented by $\mathrm{NO}_{\mathrm{z}} / \mathrm{NO}_{\mathrm{y}}$. In fact, $\mathrm{O}_{3}$ sensitivity is also influenced by several other factors (Sillman, 1999), such as $\mathrm{VOC} / \mathrm{NO}_{\mathrm{x}}$ ratio, VOC reactivity and the severity of the event (including dilution). Although the ratio of $\mathrm{NO}_{\mathrm{z}} / \mathrm{NO}_{\mathrm{y}}$ is used to represent the chemical aging, it is often affected by emissions, since the level of $\mathrm{NO}_{\mathrm{y}}$ reflects the $\mathrm{NO}_{\mathrm{x}}$ emissions (and mixing) and $\mathrm{NO}_{\mathrm{z}}$ is affected by radical concentrations, which in turn are affected by both VOCs and $\mathrm{NO}_{\mathrm{x}}$. In addition, the chemical aging is usually accompanied by the process of dilution, which alone can shift the $\mathrm{NO}_{\mathrm{x}}$-VOC sensitivity to the VOC-limited regime (Milford et al., 1994; Sillman, 1999). Milford et al. (1994) found that for plumes with same $\mathrm{VOC} / \mathrm{NO}_{\mathrm{x}}$ emission ratios, plumes with higher $\mathrm{NO}_{\mathrm{x}}$ emissions tend to be more VOC-limited, and plumes with lower $\mathrm{NO}_{\mathrm{x}}$ emissions tend to become $\mathrm{NO}_{\mathrm{x}}-$ limited more quickly as they are photochemically processed. Therefore it should be noted that when discussing the $\mathrm{O}_{3}$ chemistry - chemical aging relationship, many other physical and chemical processes are often inevitably involved.

\subsection{Comparison of findings with the MCMA-2003 Field Campaign}

During MCMA-2003 field campaign, Lei et al. (2007, 2008) investigated the relationships between ozone production rate, radical primary source, and VOC-to- $\mathrm{NO}_{2}$ reactivity using identical or similar model (an older version in the 2007 paper), finding that the urban core area was VOC-limited during the $\mathrm{O}_{3}$-South, Cold-Surge, and $\mathrm{O}_{3}$-North episodes. This was further analyzed by the simulations using three different emissions control strategies. Similar findings are obtained during the MCMA-2006 field campaign under different meteorological conditions. However, the degree of 

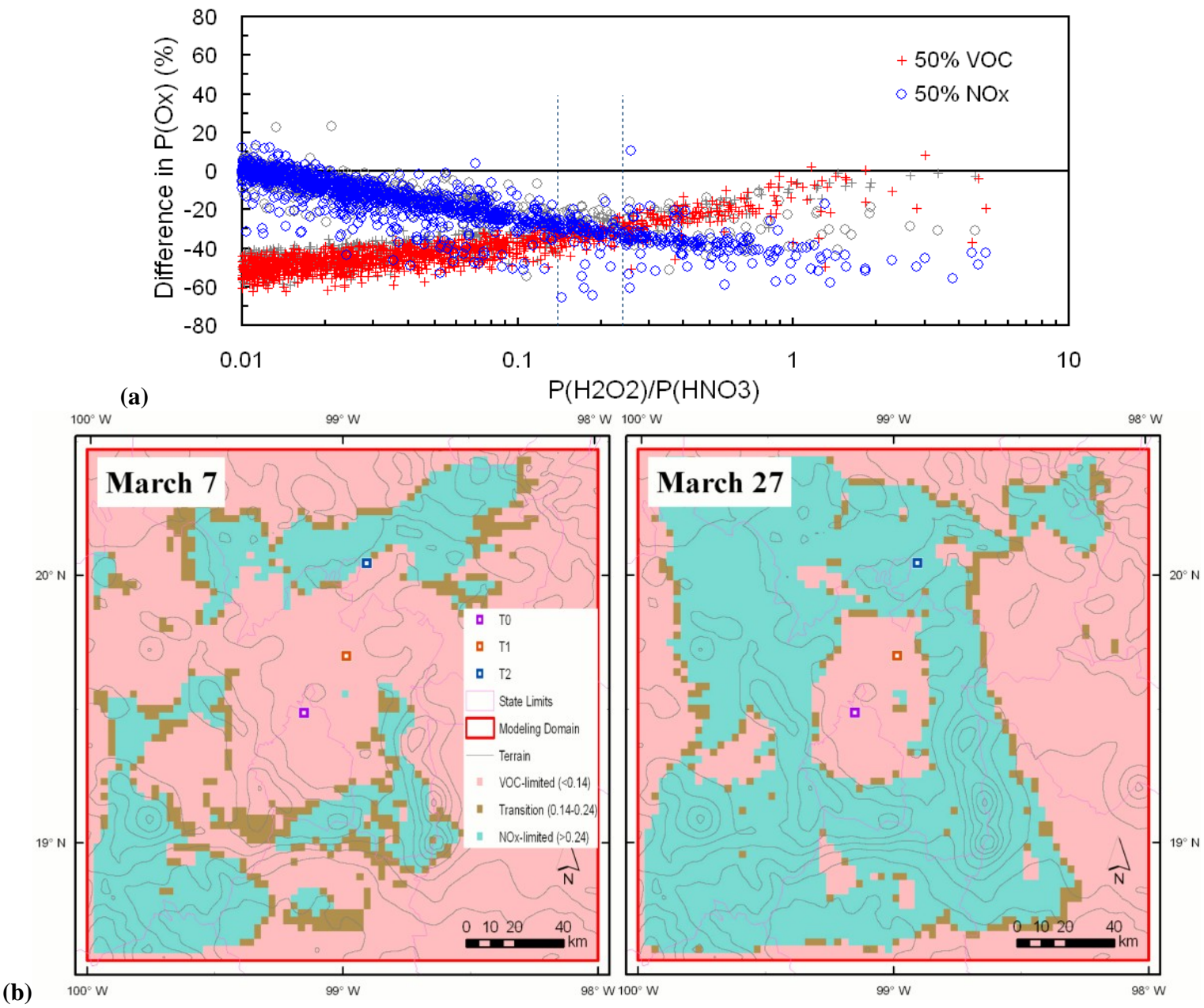

Fig. 12. (a) The percentage change in $\mathrm{O}_{\mathrm{x}}$ formation rate as a function of the indicator, ratio of $\mathrm{H}_{2} \mathrm{O}_{2}$ production rate to $\mathrm{HNO}_{3}$ production rate at 12:00-17:00 LT during the episodes (weekends are shown in gray) within the urban area. The dashed bars envelop the transition regime. (b) Spatial distribution of the ratio at 14:00 LT on 7 and 27 March indicating the $\mathrm{NO}_{\mathrm{x}}$-VOC sensitivity. Topography contour intervals are $400 \mathrm{~m}$.

the VOC-limitation increases as shown in Figs. 10 and 13. The $\Delta \mathrm{P}\left(\mathrm{O}_{\mathrm{x}}\right)-\mathrm{NO}_{\mathrm{x}}$ relationship shown in Fig. 14 also indicates that the transition area between VOC-sensitive and $\mathrm{NO}_{\mathrm{x}}$-sensitive regimes is much more narrow and shifts to lower $\mathrm{NO}_{\mathrm{x}}$ levels in MCMA-2006 compared to the MCMA2003, and the relationship for the $\mathrm{NO}_{\mathrm{x}}$-reduction case is more monotonic. These illustrate that $\mathrm{O}_{3}$ formation in the urban area during the MCMA-2006 is more VOC-limited. We attribute the difference in the degree of VOC-limitation to the chemistry . Meteorologically, Shaw et al. (2007) evaluated the vertical mixing during MILAGRO and found it to be similar to prior studies. de Foy et al. (2008) found that March 2006 was climatologically representative of the warm dry season. Compared with April 2003, there were fewer wet days and more warm winds from the south but overall the transport patterns were similar. The difference is probably mainly due to the reduced VOC reactivity and lower VOCs in the estimated emissions in 2006, as indicated by the overall $\sim 20 \%$ decrease in VOC emissions and significant decreases in emissions of reactive alkenes and aromatics. The $6 \%$ increase of $\mathrm{NO}_{\mathrm{x}}$ emissions can also contribute to the tendency, but probably with a minor impact due to the moderate increase. Although not shown in Fig. 14 (because almost all weekend data points would be overlapped with the weekdays counterparts), the $\mathrm{O}_{3}$ formation response to the emission change on weekends is very similar to that of weekdays, consistent with the results using $\mathrm{P}\left(\mathrm{H}_{2} \mathrm{O}_{2}\right) / \mathrm{P}\left(\mathrm{HNO}_{3}\right)$ ratio as indicator.

The comparison between the MCMA-2003 and MCMA$2006 \mathrm{O}_{3}$ chemistry allow us to estimate, to a certain extent, how emissions uncertainties may affect the conclusions of this study. Our model-based evaluation of VOC emissions relies on the assumption that the observations contain the full spectrum of the lumped model species such that the comparison can be made. However, it is likely that some VOC compounds are missed by the measurement techniques, in 

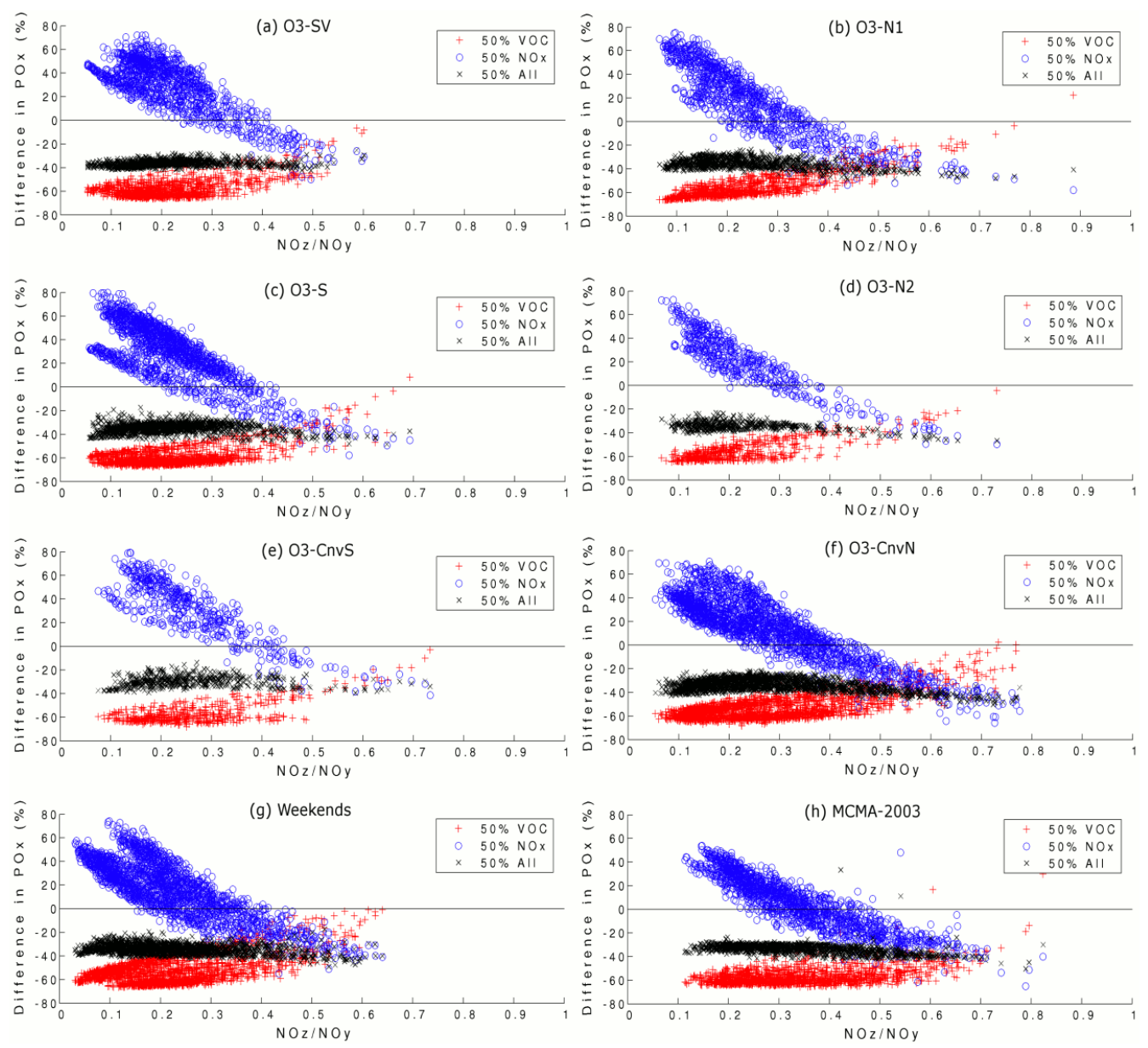

Fig. 13. Percentage change of $\mathrm{P}\left(\mathrm{O}_{\mathrm{x}}\right)$ as a function of chemical aging in the urban area at 12:00-17:00 LT during (a-g) MCMA-2006 and (h) MCMA-2003. (a-g) were sampled on weekdays during different meteorological episodes, (g) was sampled on weekends, and (h) was sampled during a $\mathrm{O}_{3}$-South episode. Young air mass on the left (low $\mathrm{NO}_{\mathrm{z}} / \mathrm{NO}_{\mathrm{y}}$ values) and aged air mass on the right (high $\mathrm{NO}_{\mathrm{z}} / \mathrm{NO}_{\mathrm{y}}$ values).

particular those with high molecular weights and low atmospheric concentrations. One way to examine the VOC measurement completeness is to compare the directly observed $\mathrm{OH}$ reactivity contributed to VOCs with its VOC measurement-derived counterpart. Such a comparison was made during MCMA-2003 (Shirley et al., 2006), and it was found that the latter was about $20 \%$ lower than the former. The consistency between observational evidence (Stephens et al., 2008; Nunnermacker et al., 2008; Wood et al., 2009) and this modeling study regarding the $\mathrm{O}_{3}$ chemical regimes in the MCMA strongly suggests that the uncertainties introduced by the missing VOCs are not sufficient to affect our conclusions. Although the magnitude of the unmeasured VOCs is unknown and its estimation is beyond the scope of this study, the comparison between MCMA-2003 and MCMA-2006 $\mathrm{O}_{3}$ chemistry indicate that up to $25 \%$ differences in VOCs (up to $50 \%$ for aromatics) do not reverse the chemical regime, but can alter the magnitude of the $\mathrm{O}_{3}$ sensitivity. It should be pointed out under what emissions reduction scenarios the $\mathrm{O}_{3}$ sensitivity chemistry is defined. If smaller emission reductions are applied (such as 20\%), the $\mathrm{O}_{3}$ chemical regime might change.

\section{Conclusions}

We have extended the MCMA-2003 study of Lei et al. (2007, 2008) to the MCMA-2006 field campaign using CAMx v4.40 that was driven by observation-budged WRF meteorology. This study not only examined more meteorological episodes, but also encompassed a wider region with updated emissions. Several major questions were addressed under different meteorological condition.

Due to uncertainties in the emission inventory, emissions of $\mathrm{CO}, \mathrm{NO}_{\mathrm{x}}$, and VOCs were compared to the measurements from air quality monitoring sites and from the MCMA-2006 field campaign. Simulations with $\mathrm{CO}$ and $\mathrm{NO}_{\mathrm{x}}$ emissions 
(a) MCMA-2006

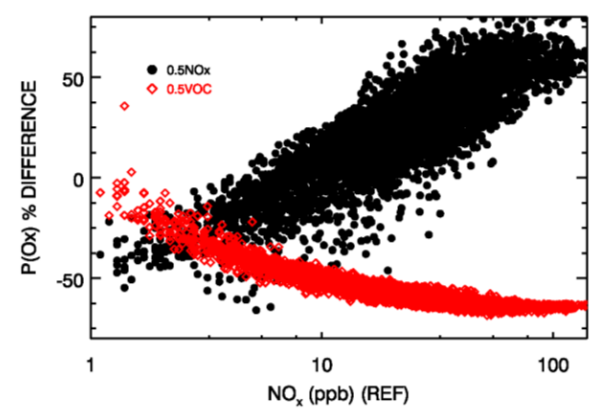

(b) MCMA-2003

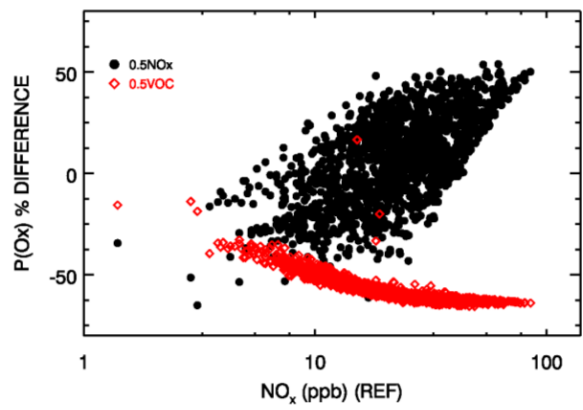

Fig. 14. Simulated percentage change of $\mathrm{P}\left(\mathrm{O}_{\mathrm{x}}\right)$ as a function of base case $\mathrm{NO}_{\mathrm{x}}$ in the urban area at 12:00-17:00 LT during (a) MCMA-2006 and (b) MCMA-2003. Datapoints in (a) include weekdays only throughout the whole episode.

from the official 2006 emission inventory agreed well with the observations, while emissions of speciated VOCs required further adjustments. Overall, total VOC emissions were underestimated by $18-23 \%$ which is much smaller than the results found in Lei et al. (2007, 2008), with significant decreases in the $\mathrm{OH}$ reactivities of alkenes and aromatics. With adjusted emissions, simulated ozone precursors and ozone concentrations were compared to observations from a variety of measurements, including surface measurements and aircraft measurements, under different meteorological episodes. Except for a few days, the observed concentrations of ozone and ozone precursors at the surface were reasonably well reproduced by the model. The peaks from aircraft measurements were also well predicted by the model. The combination of surface and aircraft measurements allow the evaluation of the simulated vertical distribution of $\mathrm{CO}, \mathrm{VOC}$, and $\mathrm{O}_{3}$ concentrations as well as an evaluation of the local emission inventory.

To determine the relative benefits of $\mathrm{VOC}$ and $\mathrm{NO}_{\mathrm{x}}$ controls, we have examined the relationships among net photochemical formation rates, radical primary sources, and $\mathrm{NO}_{\mathrm{x}}$ oxidation rates in the MCMA urban area. We also have examined the ratio of the production rates of hydrogen peroxide and nitric acid, $\mathrm{P}_{\mathrm{H}_{2} \mathrm{O}_{2}} / \mathrm{P}_{\mathrm{HNO}_{3}}$ in the urban area and mountain/rural areas. Within the urban area, $\mathrm{O}_{\mathrm{x}}$ formation was largely determined by the radical sources available, and the reaction of radicals with $\mathrm{NO}_{\mathrm{x}}$ represented the dominant radical sink, which implied that the urban area is VOCsensitive regardless of meteorological conditions. This was also shown from the spatial distribution of $\mathrm{P}_{\mathrm{H}_{2} \mathrm{O}_{2}} / \mathrm{P}_{\mathrm{HNO}_{3}}$. In contrast, ozone formation in the mountain areas or low $\mathrm{NO}_{\mathrm{x}}$ emitting rural areas was mostly $\mathrm{NO}_{\mathrm{x}}$-limited depending on meteorological conditions.

We have also examined the sensitivities of ozone production to precursor emissions during the MCMA-2006 field campaign. Independent of different meteorological episodes, reductions in VOC emissions always led to unanimous decrease in ozone concentrations, as the case in most polluted urban atmospheres. In contrast, reductions in $\mathrm{NO}_{\mathrm{x}}$ emis- sions led to large increases in the urban area and decreases in mountain/rural areas. However, spatial distributions of changes in ozone concentrations were highly sensitive to the meteorological episode. This was more evident when both VOC and $\mathrm{NO}_{\mathrm{x}}$ emissions were reduced because ozone concentrations in the urban area experienced both increase and decrease depending on the direction of the plume.

Overall, ozone formation in the urban core area was VOClimited under different meteorological episodes, while the surrounding areas with relatively low $-\mathrm{NO}_{\mathrm{x}}$ emissions can be either $\mathrm{NO}_{\mathrm{x}}$ - or VOC-limited regime depending on the episode. Our results from MCMA-2006 suggest that the controls on VOC emissions would be a more effective way to reduce ozone concentrations in the urban area, which is consistent with our previous results from the MCMA-2003 field campaign. However, the degree of VOC-limitation increased for MCMA-2006 due to reduced VOCs, reduced VOC reactivity and moderately higher $\mathrm{NO}_{\mathrm{x}}$ emissions in the estimated emissions. Furthermore, meteorological conditions led to large variations in regime for the relatively low- $\mathrm{NO}_{\mathrm{x}}$ emitting area, implying that emission controls would depend on location and meteorology.

In this study we did not include the biomass burning emissions. It is well known that biomass burning emissions are important contributor to the $\mathrm{O}_{3}$ precursor and PM emissions, and can significantly affect $\mathrm{O}_{3}$ levels and PM loading in the MCMA, even though their contributions ate highly uncertain (e.g., Yokelson et al., 2007, 2009; Moffet et al. , 2008; Stone et al., 2008, etc.). The effect of biomass burning on $\mathrm{O}_{3}$ formation (and PM) and its sensitivity in the MCMA and its surroundings is an important issue, and we plan to address it in future study.

Acknowledgements. We are indebted to the large number of people involved in the MILAGRO campaign as well as those involved in long-term air quality monitoring and the emissions inventory in the Mexico City metropolitan area, which made this study possible. In particular, we are grateful to Christine Wiedinmyer for her assistance with the MEGAN simulations, the Government of the Federal District for providing point emissions data outside 
of the MCMA; the researchers from the University of California at Irvine, Aerodyne Research Inc., Washington State University, BNL and PNNL for making their data available to constrain our chemical transport model. We thank Ezra Wood for his valuable discussions on the ARI QC-TILDAS measurements. The authors also acknowledge the anonymous reviewers for their valuable comments, which helped to improve the quality of this article. The WRF computer time was provided by the National Center for Atmospheric Research, which is sponsored by the National Science Foundation. This work was supported by the US Department of Energy's Atmospheric Sciences Program (DE-FG02-05ER63980), the US National Science Foundation's Atmospheric Chemistry Program (ATM-0528227 and ATM-810931), Mexico's Comisión Ambiental Metropolitana and the Molina Center for Energy and the Environment.

Edited by: S. Madronich

\section{References}

Apel, E. C., Emmons, L. K., Karl, T., Flocke, F., Hills, A. J., Madronich, S., Lee-Taylor, J., Fried, A., Weibring, P., Walega, J., Richter, D., Tie, X., Mauldin, L., Campos, T., Weinheimer, A., Knapp, D., Sive, B., Kleinman, L., Springston, S., Zaveri, R., Ortega, J., Voss, P., Blake, D., Baker, A., Warneke, C., Welsh-Bon, D., de Gouw, J., Zheng, J., Zhang, R., Rudolph, J., Junkermann, W., and Riemer, D. D.: Chemical evolution of volatile organic compounds in the outflow of the Mexico City Metropolitan area, Atmos. Chem. Phys., 10, 2353-2375, 2010, http://www.atmos-chem-phys.net/10/2353/2010/.

Boylan, J. W. and Russell, A. G.: PM and light extinction model performance metrics, goals, and criteria for three-dimensional air quality models, Atmos. Environ., 40, 4946-4959, 2006.

Byun, D. W.: Dynamically consistent formulations in meteorological and air quality models for multiscale atmospheric studies. Part I: Governing equations in a generalized coordinate system, J. Atmos. Sci., 56, 3789-3807, 1999.

Carter, W.: Implementation of the SAPRC-99 chemical mechanism into the Models-3 framework. Report to the United States Environmental Protection Agency, http://www.cert.ucr.edu/ carter/ absts.htm\#s99mod3, 29 January 2000.

Chameides, W. L., Fehsenfeld, F., Rodgers, M. O., Cardelino, C., Martinez, J., Parrish, D., Lonneman, W., Lawson, D. R., Rasmussen, R. A., Zimmerman, P., Greenberg, J., Mlddleton, P., and Wang, T.: Ozone Precursor Relationships in the Ambient Atmosphere, J. Geophys. Res., 97(D5), 6037-6055, 1992.

Daum, P. H., Kleinman, L., Imre, D. G., Nunnermacker, L. J., Lee, Y.-N., Springston, S. R., Newman, L., and Weinstein-Llyod, J.: Analysis of the processing of Nashville urban emission on July 3 and July 18, 1995, J. Geophys. Res., 105, 9155-9164, 2000.

de Gouw, J. A., Welsh-Bon, D., Warneke, C., Kuster, W. C., Alexander, L., Baker, A. K., Beyersdorf, A. J., Blake, D. R., Canagaratna, M., Celada, A. T., Huey, L. G., Junkermann, W., Onasch, T. B., Salcido, A., Sjostedt, S. J., Sullivan, A. P., Tanner, D. J., Vargas, O., Weber, R. J., Worsnop, D. R., Yu, X. Y., and Zaveri, R.: Emission and chemistry of organic carbon in the gas and aerosol phase at a sub-urban site near Mexico City in March 2006 during the MILAGRO study, Atmos. Chem. Phys.,
9, 3425-3442, 2009,

http://www.atmos-chem-phys.net/9/3425/2009/.

de Foy, B., Caetano, E., Magaña, V., Zitácuaro, A., Cárdenas, B., Retama, A., Ramos, R., Molina, L. T., and Molina, M. J.: Mexico City basin wind circulation during the MCMA-2003 field campaign, Atmos. Chem. Phys., 5, 2267-2288, 2005, http://www.atmos-chem-phys.net/5/2267/2005/.

de Foy, B., Fast, J. D., Paech, S. J., Phillips, D., Walters, J. T., Coulter, R. L., Martin, T. J., Pekour, M. S., Shaw, W. J., Kastendeuch, P. P., Marley, N. A., Retama, A., and Molina, L. T.: Basinscale wind transport during the MILAGRO field campaign and comparison to climatology using cluster analysis, Atmos. Chem. Phys., 8, 1209-1224, 2008,

http://www.atmos-chem-phys.net/8/1209/2008/.

Dusanter, S., Vimal, D., Stevens, P. S., Volkamer, R., and Molina, L. T.: Measurements of $\mathrm{OH}$ and $\mathrm{HO}_{2}$ concentrations during the MCMA-2006 field campaign - Part 1: Deployment of the Indiana University laser-induced fluorescence instrument, Atmos. Chem. Phys., 9, 1665-1685, 2009a,

http://www.atmos-chem-phys.net/9/1665/2009/.

Dusanter, S., Vimal, D., Stevens, P. S., Volkamer, R., Molina, L. T., Baker, A., Meinardi, S., Blake, D., Sheehy, P., Merten, A., Zhang, R., Zheng, J., Fortner, E. C., Junkermann, W., Dubey, M., Rahn, T., Eichinger, B., Lewandowski, P., Prueger, J., and Holder, H.: Measurements of $\mathrm{OH}$ and $\mathrm{HO}_{2}$ concentrations during the MCMA-2006 field campaign - Part 2: Model comparison and radical budget, Atmos. Chem. Phys., 9, 6655-6675, 2009b, http://www.atmos-chem-phys.net/9/6655/2009/.

Emmons, L. K., Apel, E. C., Lamarque, J.-F., Hess, P. G., Avery, M., Blake, D., Brune, W., Campos, T., Crawford, J., DeCarlo, P. F., Hall, S., Heikes, B., Holloway, J., Jimenez, J. L., Knapp, D. J., Kok, G., Mena-Carrasco, M., Olson, J., O’Sullivan, D., Sachse, G., Walega, J., Weibring, P., Weinheimer, A., and Wiedinmyer, C.: Impact of Mexico City emissions on regional air quality from MOZART-4 simulations, Atmos. Chem. Phys. Discuss., 10, 3457-3498, 2010,

http://www.atmos-chem-phys-discuss.net/10/3457/2010/.

ENVIRON: Users Guide to the Comprehensive Air Quality. Model with Extensions (CAMx) version 4.40, available at http://www. camx.com, 2006.

Fortner, E. C., Zheng, J., Zhang, R., Berk Knighton, W., Volkamer, R. M., Sheehy, P., Molina, L., and André, M.: Measurements of Volatile Organic Compounds Using Proton Transfer Reaction Mass Spectrometry during the MILAGRO 2006 Campaign, Atmos. Chem. Phys., 9, 467-481, 2009, http://www.atmos-chem-phys.net/9/467/2009/.

Guenther, A., Karl, T., Harley, P., Wiedinmyer, C., Palmer, P. I., and Geron, C.: Estimates of global terrestrial isoprene emissions using MEGAN (Model of Emissions of Gases and Aerosols from Nature), Atmos. Chem. Phys., 6, 3181-3210, 2006, http://www.atmos-chem-phys.net/6/3181/2006/.

Guenther, A.: Corrigendum to "Estimates of global terrestrial isoprene emissions using MEGAN (Model of Emissions of Gases and Aerosols from Nature)" published in Atmos. Chem. Phys., 6, 3181-3210, 2006, Atmos. Chem. Phys., 7, 4327-4327, 2007, http://www.atmos-chem-phys.net/7/4327/2007/.

Hong, S.-Y., Dudhia, J., and Chen, S.-H.: A revised approach to ice microphysical processes for the parameterization of clouds and precipitation, Mon. Weather Rev., 132, 103-120, 2004. 
Kain, J. S. and Fritsch, J. M.: Convective parameterization for mesoscale models: The Kain-Fritcsh scheme, The representation of cumulus convection in numerical models, edited by: Emanuel, K. A. and Raymond, D. J., Amer. Meteor. Soc., 246 pp., 1993.

Kleinman, L. I., Daum, P. H., Lee, J. H., Lee, Y.-N., Nunnermacker, L. J., Springston, S. R., Newman, L., Weinstein-Lloyd, J., and Sillman, S.: Dependence of ozone production on NO and hydrocarbons in the troposphere, Geophys. Res. Lett., 24, 2299-2302, 1997.

Kleinman, L. I.: The dependence of tropospheric ozone production rate on ozone precursors, Atmos. Environ., 39, 575-586, 2005.

Kleinman, L. I., Springston, S. R., Daum, P. H., Lee, Y.-N., Nunnermacker, L. J., Senum, G. I., Wang, J., Weinstein-Lloyd, J., Alexander, M. L., Hubbe, J., Ortega, J., Canagaratna, M. R., and Jayne, J.: The time evolution of aerosol composition over the Mexico City plateau, Atmos. Chem. Phys., 8, 1559-1575, 2008, http://www.atmos-chem-phys.net/8/1559/2008/.

Lei, W., de Foy, B., Zavala, M., Volkamer, R., and Molina, L. T.: Characterizing ozone production in the Mexico City Metropolitan Area: a case study using a chemical transport model, Atmos. Chem. Phys., 7, 1347-1366, 2007,

http://www.atmos-chem-phys.net/7/1347/2007/.

Lei, W., Zavala, M., de Foy, B., Volkamer, R., and Molina, L. T.: Characterizing ozone production and response under different meteorological conditions in Mexico City, Atmos. Chem. Phys., 8, 7571-7581, 2008, http://www.atmos-chem-phys.net/8/7571/2008/.

Lei, W., Zavala, M., de Foy, B., Volkamer, R., Molina, M. J., and Molina, L. T.: Impact of primary formaldehyde on air pollution in the Mexico City Metropolitan Area, Atmos. Chem. Phys., 9, 2607-2618, 2009, http://www.atmos-chem-phys.net/9/2607/2009/.

Liu, Y., Bourgeois, A., Warner, T., Swerdlin, S., and Hacker, J.: Implementation of observation-nudging based FDDA into WRF for supporting ATEC test operations. 2005 WRF Users Workshop, Boulder, Colorado, June, 2005.

Mena-Carrasco, M., Carmichael, G. R., Campbell, J. E., Zimmerman, D., Tang, Y., Adhikary, B., D'allura, A., Molina, L. T., Zavala, M., García, A., Flocke, F., Campos, T., Weinheimer, A. J., Shetter, R., Apel, E., Montzka, D. D., Knapp, D. J., and Zheng, W.: Assessing the regional impacts of Mexico City emissions on air quality and chemistry, Atmos. Chem. Phys., 9, 37313743, 2009,

http://www.atmos-chem-phys.net/9/3731/2009/.

Milford, J., Gao, D., Sillman, S., Blossey, P., and Russell, A. G.: Total reactive nitrogen $\left(\mathrm{NO}_{\mathrm{y}}\right)$ as an indicator for the sensitivity of ozone to $\mathrm{NO}_{\mathrm{x}}$ and hydrocarbons, J. Geophys. Res., 99, 35333542, 1994.

Moffet, R. C., de Foy, B., Molina, L. T., Molina, M. J., and Prather, K. A.: Measurement of ambient aerosols in northern Mexico City by single particle mass spectrometry, Atmos. Chem. Phys., 8, 4499-4516, 2008, http://www.atmos-chem-phys.net/8/4499/2008/.

Molina, L. T. and Molina, M. J.: Air Quality in the Mexico Megacity: An Integrated Assessment, Kluwer, Boston, 384 pp., 2002.

Molina, L. T., Kolb, C. E., de Foy, B., Lamb, B. K., Brune, W. H., Jimenez, J. L., Ramos-Villegas, R., Sarmiento, J., ParamoFigueroa, V. H., Cardenas, B., Gutierrez-Avedoy, V., and Molina, M. J.: Air quality in North America's most populous city overview of the MCMA-2003 campaign, Atmos. Chem. Phys., 7, 2447-2473, 2007,

http://www.atmos-chem-phys.net/7/2447/2007/.

Molina, M. J. and Molina, L. T.: Megacities and Atmospheric Pollution, J. Air Waste Manage. Assoc., 54, 644-680, 2004.

Molina, L. T., Madronich, S., Gaffney, J. S., Apel, E., de Foy, B., Fast, J., Ferrare, R., Herndon, S., Jimenez, J. L., Lamb, B., Osornio-Vargas, A. R., Russell, P., Schauer, J. J., Stevens, P. S., and Zavala, M.: An overview of the MILAGRO 2006 campaign: Mexico City emissions and their transport and transformation, Atmos. Chem. Phys. Discuss., 10, 7819-7983, 2010, http://www.atmos-chem-phys-discuss.net/10/7819/2010/.

Nelson, D.D., McManus, B., Urbanski, S., Herndon, S., and Zahniser, M. S.: High precision measurements of atmospheric nitrous oxide and methane using thermoelectrically cooled midinfrared quantum cascade lasers and detectors, Spectroc Acta Pt A-Molec Biomolec Spectr, 60(14), 3325-3335, 2004.

Noh, Y., Cheon, W.-G., Hong, S.-Y., and Raasch, S.: Improvement of the K-profile model for the planetary boundary layer based on large eddy simulation data, Bound.-Layer Meteor., 107, 401427, 2003.

Nunnermacker, L. J., Weinstein-Lloyd, J. B., Hillery, B., Giebel, B., Kleinman, L. I., Springston, S. R., Daum, P. H., Gaffney, J., Marley, N., and Huey, G.: Aircraft and ground-based measurements of hydroperoxides during the 2006 MILAGRO field campaign, Atmos. Chem. Phys., 8, 7619-7636, 2008, http://www.atmos-chem-phys.net/8/7619/2008/.

Shaw, W. J., Pekour, M. S., Coulter, R. L., Martin, T. J., and Walters, J. T.: The daytime mixing layer observed by radiosonde, profiler, and lidar during MILAGRO, Atmos. Chem. Phys. Discuss., 7, 15025-15065, 2007, http://www.atmos-chem-phys-discuss.net/7/15025/2007/.

Sheehy, P. M., Volkamer, R., Molina, L. T., and Molina, M. J.: Oxidative capacity of the Mexico City atmosphere - Part 2: A $\mathrm{RO}_{\mathrm{X}}$ radical cycling perspective, Atmos. Chem. Phys. Discuss., 8, 5359-5412, 2008,

http://www.atmos-chem-phys-discuss.net/8/5359/2008/.

Shirley, T. R., Brune, W. H., Ren, X., Mao, J., Lesher, R., Cardenas, B., Volkamer, R., Molina, L. T., Molina, M. J., Lamb, B., Velasco, E., Jobson, T., and Alexander, M.: Atmospheric oxidation in the Mexico City Metropolitan Area (MCMA) during April 2003, Atmos. Chem. Phys., 6, 2753-2765, 2006, http://www.atmos-chem-phys.net/6/2753/2006/.

Sillman, S.: The use of $\mathrm{NO}_{y}, \mathrm{H}_{2} \mathrm{O}_{2}$, and $\mathrm{HNO}_{3}$ as indicators for ozone- $\mathrm{NO}_{\mathrm{X}}$-hydrocarbon sensitivity in urban locations, J. Geophys. Res., 100, 14175-14188, 1995.

Sillman, S.: The relation between ozone, $\mathrm{NO}_{\mathrm{x}}$ and hydrocarbons in urban and polluted rural environments, Atmos. Environ., 33, 1821-1845, 1999.

Sillman, S. and West, J. J.: Reactive nitrogen in Mexico City and its relation to ozone-precursor sensitivity: results from photochemical models, Atmos. Chem. Phys., 9, 3477-3489, 2009, http://www.atmos-chem-phys.net/9/3477/2009/.

Skamarock, W. C., Klemp, J. B., Dudhia, J., Gill, D. O., Barker, D. M., Wang, W., and Powers, J. G.: A description of the advanced research WRF version 2, NCAR Technical Note, NCAR/TN468+STR, 8 pp., 2005.

Springston, S. R., Kleinman, L. I., Brechtel, F., Lee, Y.-N., and Nunnermacker, L. J.: Chemical evolution of an isolated power 
plant plume during the TexAQS 2000 study, Atmos. Environ., 39, 3431-3443, 2005.

Stephens, S., Madronich, S., Wu, F., Olson, J. B., Ramos, R., Retama, A., and Muñoz, R.: Weekly patterns of Mxico City's surface concentrations of $\mathrm{CO}, \mathrm{NO}_{\mathrm{x}}, \mathrm{PM}_{10}$ and $\mathrm{O}_{3}$ during 19862007, Atmos. Chem. Phys., 8, 5313-5325, 2008,

http://www.atmos-chem-phys.net/8/5313/2008/.

Stone, E. A., Snyder, D. C., Sheesley, R. J., Sullivan, A. P., Weber, R. J., and Schauer, J. J.: Source apportionment of fine organic aerosol in Mexico City during the MILAGRO experiment 2006, Atmos. Chem. Phys., 8, 1249-1259, 2008, http://www.atmos-chem-phys.net/8/1249/2008/.

Stremme, W., Ortega, I., and Grutter, M.: Using ground-based solar and lunar infrared spectroscopy to study the diurnal trend of carbon monoxide in the Mexico City boundary layer, Atmos. Chem. Phys., 9, 8061-8078, 2009,

http://www.atmos-chem-phys.net/9/8061/2009/.

Tie, X., Madronich, S., Li, G., Ying, Z., Zhang, R., Garcia, A., LeeTaylor, J., and Liu, Y.: Characterization of chemical oxidants in Mexico City: A regional chemical dynamical model (WRFChem) study, Atmos. Environ., 41, 1989-2008, 2007.

Tie, X., Madronich, S., Li, G., Ying, Z., Weinheimer, A., Apel, E., and Campos, T.: Simulation of Mexico City plumes during the MIRAGE-Mex field campaign using the WRF-Chem model, Atmos. Chem. Phys., 9, 4621-4638, 2009,

http://www.atmos-chem-phys.net/9/4621/2009/.

Tonnesen, G. S. and Dennis, R. L.: Analysis of radical propagation efficiency to assess ozone sensitivity to hydrocarbons and $\mathrm{NO}_{\mathrm{x}}$, 1. Local indicators of instantaneous odd oxygen production sensitivity, J. Geophys. Res., 105(D7), 9213-9225, 2000.

Torres-Jardon, R.: Comparative Assessment of the Sensitivity of Ozone to Nitrogen Oxides and Volatile Organic Compounds in Two Dissimilar Metropolitan Areas of North America: Cincinnati, OH (USA) and Mexico City, DF (Mexico), Ph. D. Thesis, University of Cincinnati, 2004.

Velasco, E., Lamb, B., Westberg, H., Allwine, E., Sosa, G., ArriagaColina, J. L., Jobson, B. T., Alexander, M. L., Prazeller, P., Knighton, W. B., Rogers, T. M., Grutter, M., Herndon, S. C., Kolb, C. E., Zavala, M., de Foy, B., Volkamer, R., Molina, L. T., and Molina, M. J.: Distribution, magnitudes, reactivities, ratios and diurnal patterns of volatile organic compounds in the Valley of Mexico during the MCMA 2002 \& 2003 field campaigns, Atmos. Chem. Phys., 7, 329-353, 2007,

http://www.atmos-chem-phys.net/7/329/2007/.

Velasco, E., Pressley, S., Grivicke, R., Allwine, E., Coons, T., Foster, W., Jobson, B. T., Westberg, H., Ramos, R., Hernández, F., Molina, L. T., and Lamb, B.: Eddy covariance flux measurements of pollutant gases in urban Mexico City, Atmos. Chem. Phys., 9, 7325-7342, 2009,

http://www.atmos-chem-phys.net/9/7325/2009/.
Volkamer, R., Molina, L. T., Molina, M. J., Shirley, T., and Brune, W. H.: DOAS measurement of glyoxal as an indicator for fast VOC chemistry in urban air, Geophys. Res. Lett., 32, L08806, doi:10.1029/2005GL022616, 2005.

Volkamer, R., Sheehy, P. M., Molina, L. T., and Molina, M. J.: Oxidative capacity of the Mexico City atmosphere - Part 1: A radical source perspective, Atmos. Chem. Phys. Discuss., 7, 53655412, 2007, http://www.atmos-chem-phys-discuss.net/7/5365/2007/.

West, J. J., Zavala, M. A., Molina, L. T., Molina, M. J., San Martini, F., McRae, G. J., Sosa-Iglesias, G., and Arriaga-Colina, J. L.: Modeling ozone photochemistry and evaluation of hydrocarbon emissions in the Mexico City metropolitan area, J. Geophys. Res., 109, D19312, doi:10.1029/2004JD004614, 2004.

Wood, E. C., Herndon, S. C., Onasch, T. B., Kroll, J. H., Canagaratna, M. R., Kolb, C. E., Worsnop, D. R., Neuman, J. A., Seila, R., Zavala, M., and Knighton, W. B.: A case study of ozone production, nitrogen oxides, and the radical budget in Mexico City, Atmos. Chem. Phys., 9, 2499-2516, 2009, http://www.atmos-chem-phys.net/9/2499/2009/.

Ying, Z., Tie, X., and Li, G.: Sensitivity of ozone concentrations to diurnal variations of surface emissions in Mexico City: A WRF/Chem modeling study, Atmos. Environ., 43, 851-859, 2009.

Yokelson, R. J., Urbanski, S. P., Atlas, E. L., Toohey, D. W., Alvarado, E. C., Crounse, J. D., Wennberg, P. O., Fisher, M. E., Wold, C. E., Campos, T. L., Adachi, K., Buseck, P. R., and Hao, W. M.: Emissions from forest fires near Mexico City, Atmos. Chem. Phys., 7, 5569-5584, 2007, http://www.atmos-chem-phys.net/7/5569/2007/.

Yokelson, R. J., Crounse, J. D., DeCarlo, P. F., Karl, T., Urbanski, S., Atlas, E., Campos, T., Shinozuka, Y., Kapustin, V., Clarke, A. D., Weinheimer, A., Knapp, D. J., Montzka, D. D., Holloway, J., Weibring, P., Flocke, F., Zheng, W., Toohey, D., Wennberg, P. O., Wiedinmyer, C., Mauldin, L., Fried, A., Richter, D., Walega, J., Jimenez, J. L., Adachi, K., Buseck, P. R., Hall, S. R., and Shetter, R.: Emissions from biomass burning in the Yucatan, Atmos. Chem. Phys., 9, 5785-5812, 2009,

http://www.atmos-chem-phys.net/9/5785/2009/.

Zavala, M., Lei, W., Molina, M. J., and Molina, L. T.: Modeled and observed ozone sensitivity to mobile-source emissions in Mexico City, Atmos. Chem. Phys., 9, 39-55, 2009a,

http://www.atmos-chem-phys.net/9/39/2009/.

Zavala, M., Herndon, S. C., Wood, E. C., Onasch, T. B., Knighton, W. B., Marr, L. C., Kolb, C. E., and Molina, L. T.: Evaluation of mobile emissions contributions to Mexico City's emissions inventory using on-road and cross-road emission measurements and ambient data, Atmos. Chem. Phys., 9, 6305-6317, 2009b, http://www.atmos-chem-phys.net/9/6305/2009/.

Zhao, J. and Zhang, R. Y.: Proton transfer reaction rate constants between hydronium ion $\left(\mathrm{H}_{3} \mathrm{O}(+)\right)$ and volatile organic compounds, Atmos. Environ., 38, 2177-2185, 2004. 